\title{
THE DREAM OF MALAYAN UNITY: PRESIDENT DIOSDADO MACAPAGAL AND THE MAPHILINDO
}

\author{
Augusto V. de Viana
}

\begin{abstract}
In July 1962, a proposal to form a greater Malayan Confederation was proposed by President DiosdadoMacapagal. This proposal was to include the Philippines, the Federation of Malaya and the British territories of Singapore, Brunei, Sarawak and North Borneo. The proposal would have been a realization of a Malaya Irredenta which was dreamed of by visionaries like WenceslaoVinzons who once made an oration advocating for the unity of Malayan people working toward a common destiny. The opportunity came near as colonial powers were liquidating their possessions in post-World War II Asia, Already an earlier association, the Association of Southeast Asia was formed in 1961 and this association included non-Malay countries. The Malayan confederation which would be called MAPHILINDO was to be different. On August 5, President Macapagal issued his declaration calling for the creation of MAPHILINDO. The formation of the MAPHILINDO was met with jubilation as it was the realization of a centuries-old vision and the culmination of the anti-colonial struggle. The organization however floundered because of significant problems among the three countries. It led into a diplomatic crisis that had the possibility of widespread armed conflict. MAPHILINDO floundered and was later superseded by the present Association of Southeast Asian Nations (ASEAN). Despite its stillbirth the formation of the MAPHILINDO demonstrated fraternal relations in dealing with problems and issues among the three states of Malay origin.

\section{Background:The Irredentist Visions of Rizal, Mabini, Vinzons, Melaka and Yamin}

The dream of a united Malayan homeland traces its origin to the colonial era. Back in the 1880s Filipino patriot Jose Rizal envisioned a union of peoples of Malay origin. Many nationalists including Filipinos realized that before the coming of Europeans people of the Malay Archipelago comprising the present Philippines, Malaysia, Brunei and Indonesia freely traded with each other and its leaders were related by family ties and economic relations. The royalty of Manila, for example, traced its lineage to the royal house of Brunei. This was erased following the MagatSalamat Conspiracy when the Spaniards executed the main leaders and deported the others to far areas such as Mexico. Even during European colonization the links between the islands under different European colonizers functioned. During the Spanish campaigns against Sultan Kudarat in 1640, warriors from Ternate in the Moluccas joined the fighting against the Spaniards.
\end{abstract}




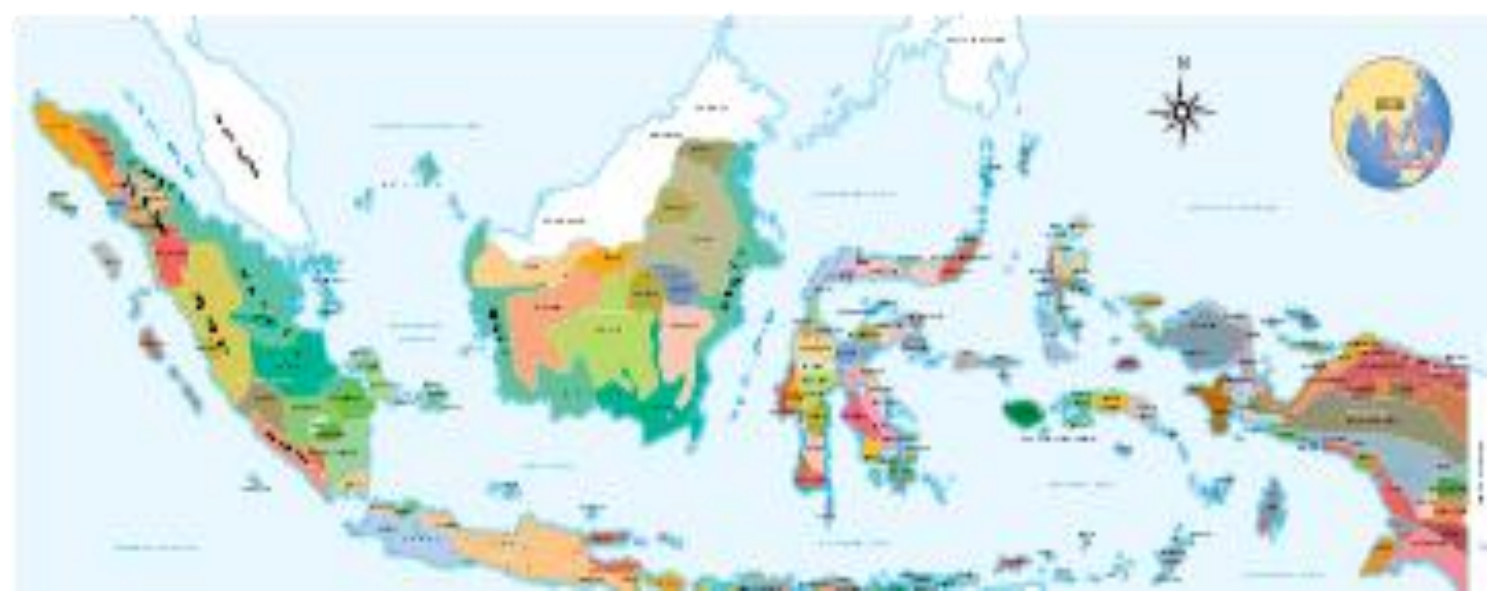

The region of Southeast Asia inhabited by people of Malay origin consisting of Indonesia, Malaysia, Brunei and the Philippines: The Great Malayan nation should be revitalized according to Irredentist views and should cast out their differences brought about byWestern colonialism.

In the $19^{\text {th }}$ century Filipino reformists and revolutionaries such as began to look at the past as inspiration for their nationalism. They realized that European colonization created a national amnesia which made the Filipinos to forget their noble past and had created barriers which shut off free contacts and commerce. Both reformists and revolutionists envisioned the restoration of this once free union of the Malay people once enjoyed by their ancestors. One of the early exponents of the rebirth of a Malay union was none other than the person whom the Filipinos considered as their foremost hero, Jose Rizal. During his time Rizal envisioned a union of peoples of Malay origin who lived in the Philippines, the East Indies, Malaya and Borneo. ${ }^{1}$ Rizal learned about the Philippines' Malayan link through the Malay language. In his exchange of letters with Austrian anthropologist Ferdinand Blumemtritt, Rizal learned that some terms in the Tagalog language was used by many Malay peoples. One such example was the word Bathala, the Tagalog word for God which was derived from the Sanskrit bhatarra which means Lord. For the Malay people the wordbatara was derived from its Sanskrit origin and it was used to refer to supreme divinities. ${ }^{2}$

Rizal exhorted his fellow Filipinos fighting for reforms from Spain to rekindle their identification with the race of their forefathers. Rizal's group was engaged in propaganda work aimed at convincing the Spanish government to grant political and social reforms in the islands and at the same time reawakening the consciousness of the Filipinos about their pre-colonial past. The Filipino propagandists got in contact with European liberals and scholars who had positive views about Malays and Malay civilization. ${ }^{3}$ Rizal's interest with the Philippines' panMalayan link increased after Blumentritt introduced him to the works of Wilhelm von Humboldt. Humboldt did a study on the Kawi language which is still a very significant work on the MalayoPolynesian comparative linguistics.

In 1889 Rizal rewrote with his own annotations a work of a $16^{\text {th }}$ century Spanish historian Antonio de Morga, the Sucesos de las Islas Filipinas (Events in the Philippine Islands) which was an account of the Philippines at the time of the early Spanish contact. In his annotation of Morga's work Rizal led the propagandists in rediscovering their Malayan identity through the history of the Philippines. Rizal emphasized that the Filipinos were never submissive because they fought for Spain's battles in Asia and against foreign invaders. He said however that Spanish rule and propaganda developed among the Filipinos a sense of colonial mentality in which they began to hate their own origins and embrace the culture of the Spaniards. Spanish 
propaganda pictured the natives of the Philippines as savages and the Philippines would not have developed culturally without Spain's influence. Rizal sought to expunge this colonial mentality through his essays especially one about the laziness of the Filipinos. ${ }^{4}$ The use of historical information that made a comparison with the freedom of the colonial past and the prevailing colonial conditions caused suspicions among the Spanish authorities who began to accuse the propagandists of separatist tendencies. ${ }^{5}$

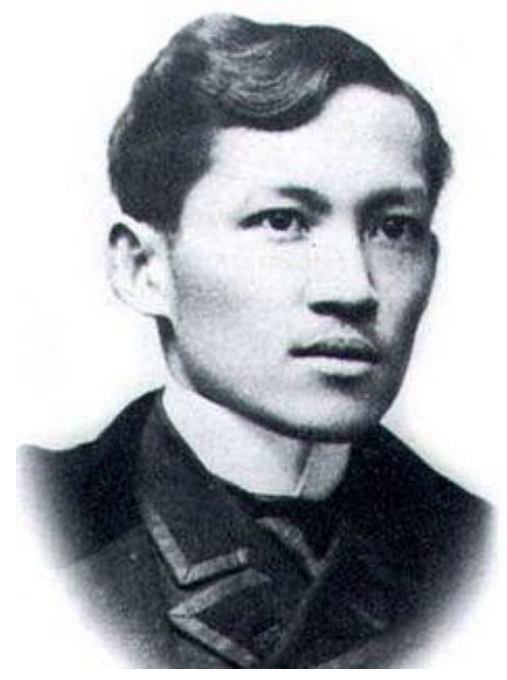

Rizal's views did not limit themselves to the

Philippines alone but to the whole of Malayan-inhabited

Southeast Asia.

Though Rizal aspired for freedom for all Malay peoples, he refrained from expressing this openly. While staying in Paris where he was annotating Morga'sSucesos, he and some fellow Filipinos formed a group called the Indios Bravos. The Indios Bravos had an inner secret group called R.d.L.M. which pledged to liberate the Malay people from colonial rule beginning with the Philippines later extending to the inhabitants of Borneo, Indonesia and Malaya. ${ }^{6}$

In 1891 Rizal personally went to Sandakan in North Borneo to negotiate for the establishment of a Filipino colony to relocate displaced farmers from his hometown in Calamba. The project fell through because of opposition by the Spanish authorities in Manila. Rizal was later implicated as the moving spirit behind the Philippine Revolution which broke out in August 1896 and died a martyr's death in Manila on December 30, 1896.

Despite of his death Rizal's vision lived on among Filipino revolutionists. ApolinarioMabini who was considered as the brains of the second phase of the Philippine Revolution during 1898-1899, saw that the final aim of the Philippine Revolution was "to give light to the gloomy night in which the vilified and degraded Malay race finds itself so that it may be led to the road of social emancipation." " Mabini's biographer Cesar Majul writes "To Mabini what the Filipino Malays of Rizal were doing were exemplary to the other peoples under the colonial yoke for it "was very contagious, having within its womb the seeds of a disease that is mortal to the colonial interests of Great Britain, Germany, France, Holland, etc.)- a dam to their overflowing ambitions in the not far away future." "It was Mabini who proposed the formation of a Federacion Malaya which is a revitalized race imbued with a new nationalism. ${ }^{9}$ 


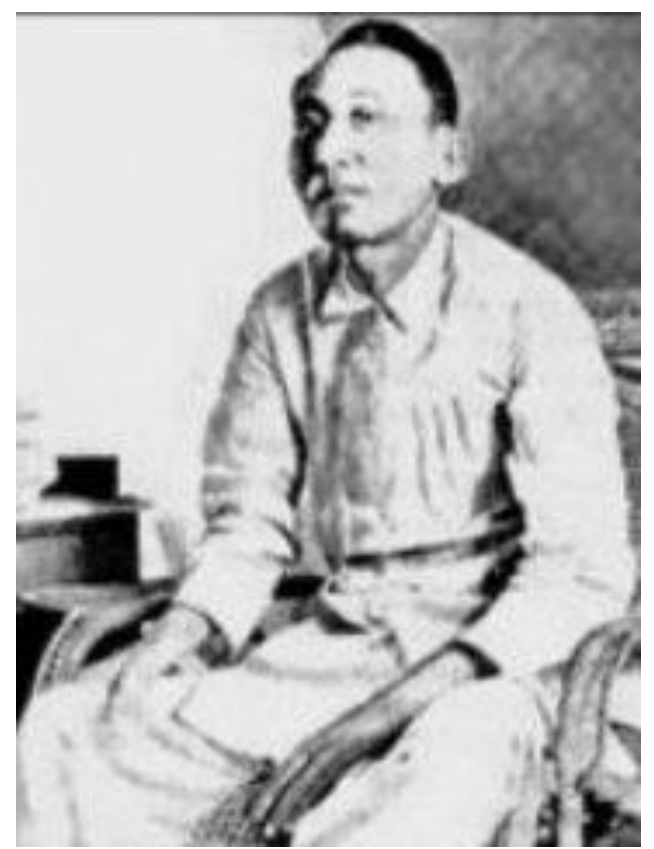

Mabini: What the Filipinos were doing in their Revolution will be dangerous to the interests of the western colonial powers.

Historical research into the great past of the Malays confirmed the earlier findings of the $19^{\text {th }}$ century historians. During the American period colonial textbooks contained findings particularly by anthropologist H. Otley Beyer pointed out that the ancestors of the Filipinos including the black Negritos to the ancestors of the Moros of Mindanao came from the Malay islands which extended from Ceylon to the Philippines. The Moros of Mindanao and Sulu were latecomers to the Philippines but all languages of the Philippines were offshoots of the Malay language. ${ }^{10}$ In 1916 J.G.R. Furlong revealed that the origin of the Malays was the foremost factor in the peopling of the Philippines. He said that the Filipinos were called the "Malas" of the Malays which was by far the most important race not only in the Indian Seas, but from Africa to Polynesia. $^{11}$

The Malays were the seafarers and colonizers in East Africa for more than one thousand years. They went to the Cape of Good Hope, colonized Malagasa (now Madagascar) and the Maldivas (Maldives), the Malaka peninsula (Malay Peninsula) and the kingdoms of Java, Celebes and the Moluca group. These Malas who came from India to colonize the Indian archipelago. who sailed from Polynesia to the Cape of Good Hope. They colonized the Malabar Coast of India of what is now Bengal, the Maldivas (the Maldives), Sri Lanka up to Madagascar. These Malays colonized what Furlong called as "Outer India" which comprised the East Indian Archipelago. He called this archipelago as "Malaysia."12

Other American authors limited their view of the Malayan ancestry for the Filipinos. Esldan Best said that from the East Indian Archipelago, the Malays who came through Kalimantan became the Tagalogs of Luzon and the Visayans of Central Philippines. He added that the Tagalog language was one of the purest of the Malay dialects. ${ }^{13}$

The development of a pan-Malayan consciousness was clearly a legacy of the Philippine propaganda movement led by Rizal and his fellow reformists and of the Philippine Revolution. Malayan consciousness grew in other territories. Many Indonesians as well as Malays began 
considering Rizal as "the Great Malayan." This revived consciousness contributed greatly to the formation of nationalist movements in the Malay world. Indonesian nationalist leaders knew about Rizal, among them was Dr. WahidinSoedirohoesodo, the first leader of the BodiUtomo (Noble Endeavor)which sought to improve Indonesian society through education. Other leaders were MohamadHusniThamrin, Vice President of the Dutch-installed People's Council (Volkskraad) and Rosihan Anwar knew about Rizal and were inspired by his works. During the Indonesian war for independence following the declaration of its independence from Dutch rule, Indonesian freedom fighters were told to memorize Rizal's last poem, the Mi Ultimo Adios and a copy of the poem translated in Malay was circulated among the Indonesian freedom fighters during the battle against the Dutch and the British in November $1945 .{ }^{14}$

In the Philippines, Rizal's vision was followed up in the $20^{\text {th }}$ century the vision of Rizal by a new crop of leaders. In 1926 a group called the Pan Malayan Union was established at the University of the Philippines. The group was comprised by students from the Philippines and some Southeast Asian countries. Among its leaders was Wenceslao Q. Vinzons, then a law student at the university. Its other leaders were TengkuUsman Hussein; Baron Sudhadfistra and Tengku S. Djaja. The Pan Malayan Union recruited students from the Philippines, Siam, the Malay Peninsula and Polynesia. The group was a miniature version of his vision- a league of Malayan brotherhood. Its aim was to promote the study of the history, civilizations and culture of the Malay race, promote intra-Malay trade and develop a sentiment of unity among all brown peoples. $^{15}$

Vinzon's dream was to realize a free Malay nation that will comprise "a million brown people." 16 This nation will not be a single state but the entire Southeast Asian nation where the people who share a common racial and cultural heritage will live in peace and freedom devoid of colonial anthem. Vinzonswas inspired by Mabini through his writings. The region of the Malays will be called a Malaysia redeemed and revitalized. He coined his world view and vision as Malaya Irredenta. ${ }^{17}$

As a young law student at the University of the Philippines Vinzons became a student leader and editor of the school paper. He founded a group called the Pan Malayan Union composed of young and idealistic students and professionals. Recruiting students from the Philippines, Siam, the Malay Peninsula and Polynesia, The group held secret rituals where the ceremonial language was Malay. Compared to Rizal's Indios Bravos, the Pan Malayan Union advocated the study of the history, culture, civilizations and culture of the Malay race, to promote intercourse in commerce and in thought, among them a sentiment of unity among all brown peoples. ${ }^{18}$

When he became a lawyer Vinzons developed the Pan Malayan Union as the Young Philippines in 1934. It was supported by prominent politicians such as Manuel Roxas, Jose P. Laurel and academicians like Dean Rafael Palma and Dean MaximoKalaw of the University of the Philippines. The group became a political party and counted young leaders like Arturo Tolentino, Carmen Planas, Maria KalawKatigbak, CamiloOsias and DiosdadoMacapagal. The Young Philippines party worked for Philippine independence and tried to secure the approval of the first Philippine Independence Law, the Hare Hawes Cutting Act. Once the Philippines achieves its independence Vinzons and his associates will work for the formation of confederation of free Malayan Republics. ${ }^{19}$

Vinzons wrote his vision in a pamphlet inspired by his slogan Malaya Irredenta. The pamphlet entitled Malayan Irredenta was translated into Malay but was immediately banned by the Dutch in Indonesia. According to Vinzons a world war will occur in a few years and he 
advocated the adoption of Pan Malayan understanding and unity if the Malayan countries would not be the Balkans of the East. ${ }^{20}$

Later Vinzons produced a publication entitled Malayan Irredenta was which was inspired by his slogan Malaya Irredenta. The name was also proposed as the name of the union. In 1932 he spoke an oration about a United Malaysia extending from the northern end of the Malay Peninsula to the shores of Polynesia. He said that this swath of territory was the "original state of Malaysia."21 The unification of this area was represented the empires of Sri Vijaya and Madjapahit empires.

The Pan Malayan Union now the Young Philippines pointed out that the Malay world which once spread from Madagascar to the East Indies was broken up by western powers. Madagascar was once a Malay kingdom before it was annexed by France; the Malay Peninsula was taken over by the British and Indonesia by the Dutch. The vision of Vinzons was to restore this Malay world by removing the colonial barriers. Vinzons predicted that war with Japan may break out in the region and the Malay brothers would become pawns of the bloody game of nations in this part of the Pacific. ${ }^{22}$

He thought that that time (1938) was the appropriate time to lay the basis of a Pan Malayan Union so the Malayan countries will not become the Balkans of the East. Vinzons also envisioned that after the war it was necessary to establish "a greater aggrupation of peoples" that transcended the present narrow national boundaries and where colonialism will find no place. $^{23}$ In such a world, "an awakened Malaysia will march with the rest of humanity towards the end of the millennium. In his mind Pan Malayan Unity and Filipinism are just two aspects of a same vision. In most of his letters he would end "Yours for a Greater Philippines" or "Yours for a Greater Malaysia." 24

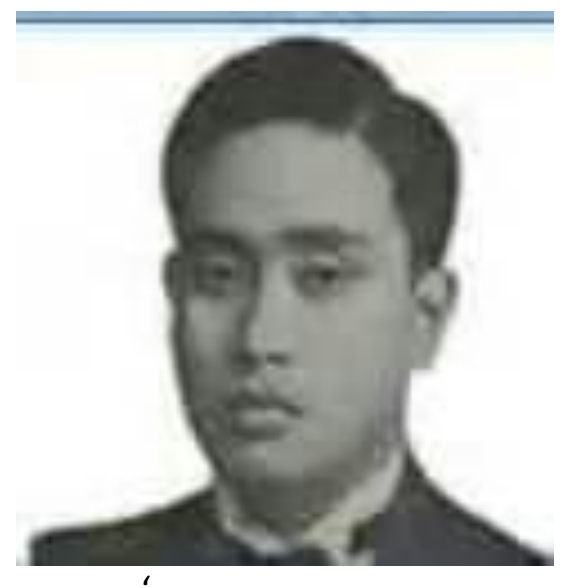

The visions of Rizal and Mabini were followed up by WenceslaoVinzons in his "Malaysia Irredenta" oration.

Vinzons later ran for political office becoming the youngest member of the 1934 Constitutional Convention which drafted the 1935 Philippine Constitution. In 1938 he was elected governor of his home province of Camarines Norte. However Vinzons did not live to see his dream of a united Malayan nation realized because of the outbreak of the Pacific War in 1941. Vinzons became a guerrilla leader in his province and was betrayed by his in-laws to the 
Japanese who captured him. The Japanese invaders wanted the young Vinzons to collaborate with them but he staunchly refused. His captors executed him in 1944.

In Indonesia and Malaya visions of a great Malayan confederation were continued by other ideologues like Tan Melaka, Muhammad Yamin and Ibrahim Ya'acob. Tan Melaka who said to have introduced communism in the Philippines, considered Rizal an intellectual in relative isolation from the masses. Like Rizal Melaka cited the extent of the Malay civilization that once stretched from Madagascar off East Africa to the East Indies. These regions were broken up by western colonization. $^{25}$

Arriving in the Philippines from Hong Kong on July 20, 1925, he passed himself off as a Filipino musician named Jorge Fuentes. He came to the Philippines upon invitation of Filipino delegates who attended the Transport Worker's Conference in 1924 in China. The Filipinos believed that Tan Melaka was a sincere nationalist and a refugee from Dutch persecution not knowing that he was a co-founder of the Parti Komunis Indonesia (PKI) and was the chief Southeast Asian representative of the Communist International (COMINTERN). During his stay in the Philippines he met Filipino leaders like Manuel Quezon, Claro M. Recto, Emilio Aguinaldo and other prominent persons. He met Filipino labor and peasant leaders among whom was Crisanto Evangelista who later founded the PartidoKomunistangPilipinas (PKP) in 1930. Tan Melaka was instrumental to sending Filipino delegates which included Crisanto Evangelista and Guillermo Capadocia to a trade conference in Canton, China in $1928 .{ }^{26}$ Two years later Evangelista founded the PKP and Capadocia became one of the first members of the party's Central Committee. While staying in the Philippines Tan Melaka advocated the formation of a pan Malayan union with Davao in Mindanao as the capital. ${ }^{27}$

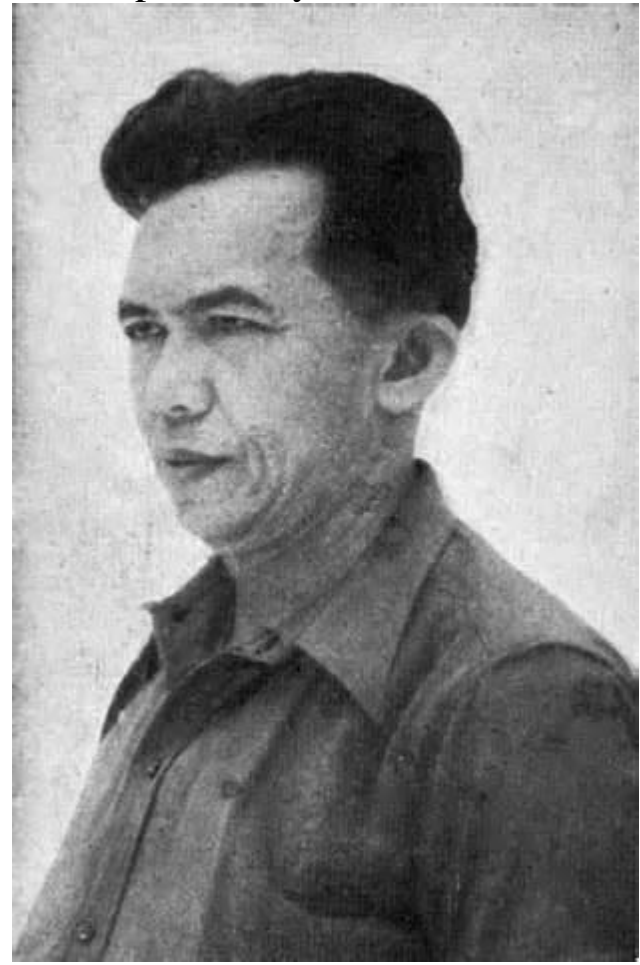

Tan Melaka envisioned a Malay Union with its capital in Davao in Mindanaoisland

Melaka was arrested by Philippine Constabulary Agents while returning to Manila from southern Indonesia. His Filipino friends did not see him as a veteran communist organizer and two of them, General Emilio Aguinaldo and former Manila Mayor Ramon Fernandez posted a 
bond for Malaka's temporary release. A prominent lawyer Pedro Abad Santos acted as his chief counsel argued for his right to stay in the Philippines as a political refugee. As the case would involve prominent Filipinos, Melaka was ordered deported to Amoy, China by Acting Governor General George Gilmore on August 22, 1927. ${ }^{28}$ As Melaka was being deported, he was viewed by Filipino leaders as a martyr for the cause of the Malays even as the American authorities told them that he was an Indonesian communist. ${ }^{29}$

Other persons who dreamed of a pan Malayan union was another Indonesian named Muhammad Yamin and Ibrahim Ya'acob of Malaya. Both men were fervent Malay nationalists who advocated the expulsion of all western colonizers. Yamin who was a lawyer from Padang, West Sumatra was a leading figure in the radical nationalist movement. With oratorical powers comparable to Sukarno in the 1930s he envisioned a greater Indonesia called Indonesia Raya that will include would include all of the Malay Peninsula, Borneo and the Philippines. Although he aligned his fervent nationalism with the Indonesian Communist Party (PKI), he joined Parindra, a moderate party after 1926 when the PKI was suppressed following an attempted rebellion against the Dutch. ${ }^{30}$

Another proponent of a Malay union was Ibrahim Ya'acob a nationalist firebrand from Pahang, Malaya. Ya'acob founded a party consisting of anti-colonial youth calling itself the KesatuanMelauMuda (Union of Malay Youth or KMM). Ya'acob advocated the formation of a fraternal cohesion of Malay-speaking peoples capable of transcending colonial boundaries. His concept was similar to that of Yamin. It was similar to the vision of Vinzons in the Philippines. In the 1930s he wrote articles critical of the British. He continued his activities until his arrest. The Japanese freed him when they defeated the British in 1941. Ya'acob formed a political party the KesatuanMelayuMuda (KMM) during the Second World War. The party advocated the achievement of independence through a union of Malaya with Indonesia. ${ }^{31}$

The ideologies of the three men were bound by a common Malay heritage, the Malay language and to an extent the Islamic religion. The KMM enunciated its vision for the "political salvation for the Malays by means of the expulsion of the British and the union of Malaya with a yet to be formed Indonesia. Immigrants from Indonesia were attracted to the KMM and they contributed to its radical and revolutionary flavor. ${ }^{32}$

During the Japanese occupation of Malaya and the Dutch East Indies Yamin, Ya'acob and Melaka cooperated with the Japanese during the occupation of Malaya and Indonesia. Their role with the invaders however tainted their characters. Yamin was accused of recruiting involuntary laborers or romusha for the Japanese. Seventy per cent of those recruited died during the occupation. Following Melaka was painted as a communist agent and a Trotskyist. He was later executed by Indonesian Republican forces. Though sidelined the visions of Yamin, Ya'acob and Melaka for a pan Malayan union lived on. Yamin later revised his vision that the new Malay union not to include the Philippines but should include Sarawak, East Timor and North Borneo. This revision was supposed to be temporary. ${ }^{33}$

\section{The Birth of the MAPHILINDO}

The dream of achieving unity along Malay nations continued into the postwar years. One of the thrusts of the Philippine government in the late 1950s was to develop closer relations with its Asian neighbors as part of the strategy of reducing its dependence on the United States and the western powers. In July 1962 President DiosdadoMacapagal proposed to form a greater Malayan confederation consisting of the Philippines, the Federation of Malaya, Singapore and the British territories of Brunei, Sarawak and North Borneo. Macapagal who was once a 
member of Vinzon's Young Philippines movement shared Vinzon's view of Malayan unity. Macapagal' announced his plan was announced during a weekly press conference that month.

The proposal to form a Malay Union was reached after meeting with Vice President Emmanuel Pelaez who was also the Philippine foreign affairs secretary, Senator LorenzoSumulong and Congressman Godofredo Ramos. The last two were chairmen of the Senate and House Committee on Foreign Relations respectively. The proposal had the support of both houses of the Philippine legislature. ${ }^{34}$ At first the proposal for a Malayan confederation did not include Indonesia which was lukewarm to the idea of an Asian regional bloc like the Association of Southeast Asia (ASA) which was formed earlier in 1961. Indonesia considered the ASA as western-inspired. With the failure of Indonesian support the ASA was considered a failure. $^{35}$

Macapagal envisioned that the Malay confederation will supersede the soon to be formed Federation of Malaysia. According to him "At the time when colonial powers were liquidating their empires in our region the time has come when we, the Malay people, must try to discover a new and broader basis for more effective cooperation and unity... I do not believe that we should leave the vital task to the outgoing colonial powers. This is a task that we Malay peoples must ourselves do... " 36

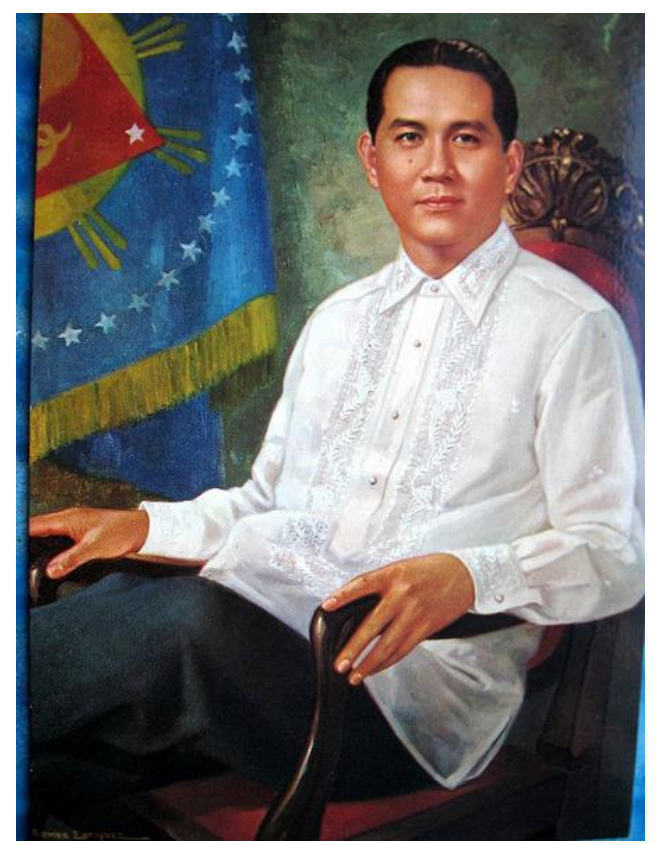

DiosdadoMacapagal: “ A Malay Union will forge 40 million Malay people into one solid bloc."

If realized the confederation will place 250,000 miles of territory and 40 million people (of the Philippines, Malaya, Singapore, Brunei, Sarawak and North Borneo) into one solid bloc. Aside from fostering fraternal relations, Macapagal intended the soon-to-be formed Malay union as an alliance against aggression and subversion. The Philippines saw the threat as a disturbance to peace with the outright incorporation of North Borneo to the soon-to-be formed Federation of Malaysia while Malaysia on the other hand saw the Philippine claim to North Borneo and the Indonesian encroachments on its territory as well as the growth of communism in Borneo as 
threats. Indonesia for its part saw the formation of Malaysia as a continuation of British influence in the region. ${ }^{37}$

Macapagal's plan faced formidable obstacles. The Philippines has a standing claim to Sabah and it was worried about the incorporation of the territory into the future Federation of Malaysia. Though the Philippines based its claim on legal documents the British government refused to discuss it and stated that it was leaving it to the government of Malaya which was incorporating North Borneo into the new federation. ${ }^{38}$

Another obstacle was the opposition of Indonesia to the formation of Malaysia. Indonesia objected to the formation of Federation of Malaysia because of the perception was that it represented the forces of neocolonialism. ${ }^{39}$

Undaunted by the British refusal, Macapagal was optimistic about his plan"The unity of the Malay peoples," he declared, " is the business of the Malay Peoples. We must forge it ourselves by our own efforts, out of our sense of history and in recognized community of interests. We should not accept a European project as a substitute for an Asian project, planned and carried out by Asians themselves, in the true and enduring sense of the Asian world...." 40

One perception to the proposed confederation of the Philippines, Malaya and Indonesia was it was a way of the Philippine government to offset its failure in its negotiations with the British government regarding its claim to Sabah. Speaking before the UN Security Council the Indonesian Deputy Foreign Minister said on September 10, 1964 that the establishment of Malaysia is not a conflict between peoples or even countries but a fight against a political concept which was neocolonialism. Both the Philippines and Indonesia were of the position that they would have no objection to its formation as long as the peoples of Borneo wished to be incorporated into the Federation. ${ }^{41}$

The plan to form the Federation of Malaysia was already known since 1961. The Indonesians already opposed it after the Brunei revolt of December 8, 1962 and declared its policy of Konfrontasi(Confrontation) with Malaya on February 11, 1963. Indonesian irregulars and volunteers then began their armed infiltration into Sarawak. To resolve the matter President Macapagal called the heads of governments of Malaya, the Philippines and Indonesia agreed to meet in Tokyo in June 1963. It was during this meeting Prime Minister Tungku Abdul Rahman, Sukarno and Macapagal discussed the formation of the forming of the MAPHILINDO. This confederation shall serve as the venue in resolving the differences between the three countries.

Some sectors saw MAPHILINDO as the third force that might become the world's third biggest economic force after the United States and the Soviet Union. Mr. SohTiangKeong, Chariman of the Indonesian Chamber of Commerce and Industry said that once firmly established, the three-nation confederation could play an important part in the global economy. ${ }^{42}$ 


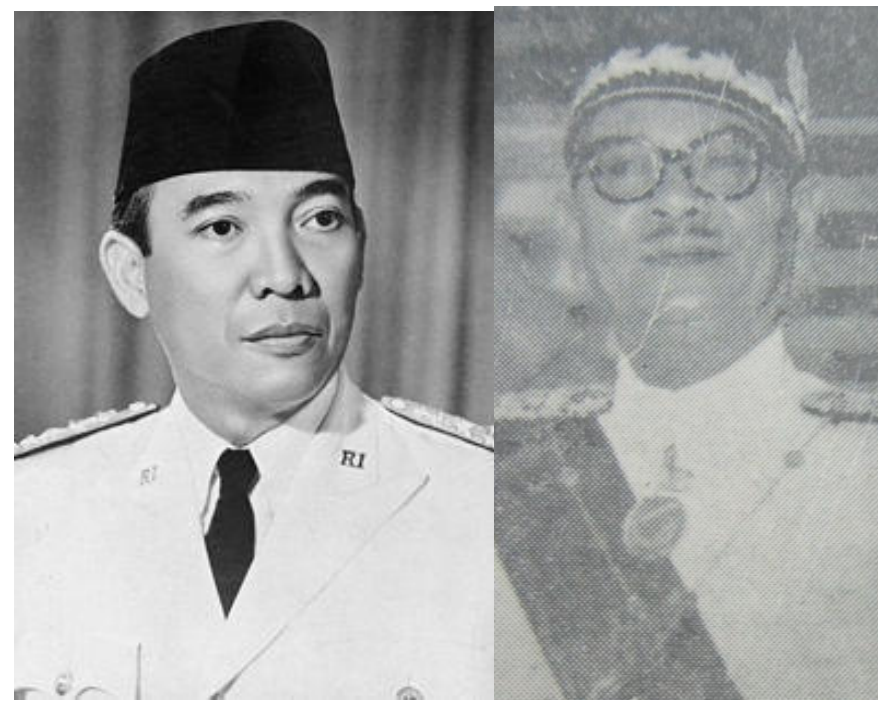

Indonesian President Sukarno and Malayan Prime Minister Abdul Rahman:

both leaders agreed to stop the confrontation between their countries and agree to presidentMacapagal's Malayan unity proposal

The planned formation of MAPHILINDO already had its critics right from the start. One criticism was that it was racially-inspired being formed along Malay lines. Various ethnic groups especially the Chinese especially in Singapore and Malaysia opposed it. The ethnic Chinese feared rumors that the MAPILINDO had "sinister implications" against them. This was denied by the Malayan Chinese Association President Tan Suw Sin. ${ }^{43}$

However it was argued that although MAPHILINDO was composed of peoples of Malay stock, its guiding principles were nonracial and it was no more racial than NATO or the Rio Pact is. ${ }^{44}$ President Macapagal said that MAPHILINDO was not racial. He said that the association formed by Malaya, the Philippines and Indonesia was merely a nucleus, an expanding association of nations in the region aimed at building a better society for themselves. ${ }^{45}$ For his part speaking from Bangkok Philippine Foreign Secretary Salvador Lopez said "MAPHILINDO is an expanding group. MAPHILINDO is not a closed association but an expanding association of like-minded nations." "This means MAPHILINDO was intended to expand to other countries in the Southeast Asian region.

Another fear was that MAPHILINDO might be "extremely dangerous" if it would become an instrument of Communist policy. This warning was revealed by a spokesman of the Malayan Ministry of External Affairs. He said that the three-nation get together could never become a reality if one member opposes another- referring to Indonesia. ${ }^{47}$

To provide the groundwork for the MAPHILINDO, foreign ministers and representatives of the , the three countries consisting of Vice President Emmanuel Pelaez, Tun Abdul Razak, the Deputy Prime Minister of Malaya and Subandrio, the Deputy First Minister/Minister for Foreign Affairs of the Republic of Indonesia, met in Manila from June 7 to 11, 1963. The meeting resulted in the drafting of the Manila Accord. The accord basically provided for a commitment to work in close harmony for the peaceful resolution of mutual problems, close cooperation in common concerns such as security, economic and cultural matters without sacrificing each other's national sovereignty.

The group also discussed the formation of Malaysia and the Philippine claim to Sabah. It was agreed that the three countries will resolve the issues through peaceful means. On the 
inclusion of North Borneo to Malaysia, it was decided that the three governments welcome the formation of Malaysia provided that the will of the people of the Borneo territories is ascertained by an independent and impartial authority like the Secretary-General of the United Nations or his representative. On the Philippine claim to Sabah it was agreed that the three countries agreed to exert their best efforts to bring the claim to a just and expeditious solution by peaceful means, such as by negotiation, conciliation, arbitration, or judicial settlement as well as other peaceful means of the parties' own choice, in conformity with the Charter of the United Nations and the Bandung Declaration. ${ }^{48}$

On July 30 to August 5, 1963, the heads of states of the Federation of Malaya, the Philippines and the Republic of Indonesia held a summit conference in Manila and ratified the Manila Accord. After marathon meetings, the three leaders agreed on the following: firstly adherence to the principle of equal rights and self-determination of peoples as enunciated in the United Nations Charter and the Bandung Declaration; secondly that they are determined, in the common interest of their countries, to maintain fraternal cooperation among their peoples in the economic, social and cultural fields in order to promote economic progress and social well-being in the region, and to put an end to the exploitation of man by man and of one nation by another; thirdly that the three nations shall combine their efforts in the common struggle against colonialism and imperialism in all their forms and manifestations and for the eradication of the vestiges of the thereof in the region in particular and the world in general; fourthly that the three nations, as new emerging forces in the region, shall cooperate in building a new and better world based on national freedom, social justice and lasting peace; and lastly the agreed to take initial steps towards the establishment of MAPHILINDO. The holding of frequent and regular consultations shall be known as MushawarahMaphilindo. ${ }^{49}$

In their joint communiqué issued following the signing of the Manila Accord it was agreed that the three countries would work inside the parameters of the UN Charter and the Bandung Declaration. They also agreed to comply with Resolution 1541 of the UN General Assembly providing for the peaceful holding of a plebiscite in Sabah and working with the UN to ascertain the elections (North Borneo) and Sarawak but nevertheless further examining and verifying and satisfying himself as to whether

(a) Malaysia was a major issue, if not the main issue;

(b) Electoral registers were properly complied;

(c) Elections were free and there was no coercion; and votes were properly polled and properly counted;

(d) And the wishes of those being qualified to vote would have exercised their right of self-determination in the recent elections had it not been for their detention for political activities, imprisonment for political offenses or absence from Sabah (North Borneo) and Sarawak. ${ }^{50}$

With the signing of the Manila Accord, the Philippines and Indonesia gave their support to the formation of Malaysia as long as the conditions in the agreement were met. Indonesia was to end its confrontation policy towards Malaya. MAPHILINDO would become part of the process towards attaining Malayan unity and cooperation. ${ }^{51}$

The formation of MAPHILINDO was met with great jubilation. Macapagal called the Manila Accord "a declaration of Asian independence." 52 The accord was seen to ensure peace between the three countries. The set of agreements consisting of the Manila Accord and the leaders' joint communiqué was seen to ensure peace between the three countries and would 
drastically change the course of events in Southeast Asia. One commentator said that the establishment of MAPHILINDO "is a prelude to the Malay Confederation of our visions. ${ }^{53} \mathrm{He}$ said "one gets the feeling that the eventual union of the Malay peoples from each other by the accidents of history, is so exhilaratingly close." They (the three countries) are determined in their respective countries to maintain fraternal relations to strengthen cooperation in the economic, social and cultural fields and social well-being of the region. These are authentic tones of a new Malay generation," he said.

\section{Diplomatic Crisis and Limbo}

In reality MAPHILINDO was still a far cry from the vision of Malay irredentists like Rizal, Vinzons, Melaka, Yamin and Ibrahim. The Manila Accord merely provided for close cooperation on social, economic and cultural fields. It did not provide for a political or even an economic union. More importantly though the MAPHILINDO professed the rejection of imperialism and neocolonialism two of its members are still very much entangled in these issues. The Philippines at that time hosts US military and naval bases and was bound by various political and economic treaties with its former colonizer. Malaya too hosted British military bases including the ones in Singapore and was dependent on British military and economic support. It left Indonesia with a neutralist though increasingly leftist stance.

Despite its serious defects, the establishment of MAPHILINDO was a right step towards the vision of a united Malaysia not limited to the former British territories but all areas inhabited by Malays. Still basking from euphoria of the formation of MAPHILINDO, Macapagal hoped that the formation of the group would lead to a golden age. He said "In MAPHILINDO and through MAPHILINDO, nourished constantly by their vision and enterprise, the Malay peoples shall be borne upon the wave of the vast, irresistible wave of the future. The aim of the MAPHILINDO is to capture the glory of the past before the coming of the West. On the other hand the three countries were headed toward a showdown over the interpretation of the Manila Accord calling for the sending of United Nations observers to a UN ascertainment regarding the formation of the Federation of Malaysia. The British were firmly opposed to allowing more than four observers in Sarawak and North Borneo (Sabah).

The Malayan Prime Minister Tungku Abdul Rahman himself urged Britain to allow more observers to watch the UN mission. The British allowed four observers and four clerical assistants into each territory to observe the UN nine man team to determine if the people of Sarawak and North Borneo agree to join the Federation of Malaysia. Prime Minister Rahman agreed with the Indonesian thinking by saying "I am happy the British government has agreed to eight observers from each country but Malaya is content to have four. He also said that he faced opposition at home for bending too much to accommodate the Filipinos and the Indonesians saying "many have already derided me for making so much concessions and lowering myself in the face of threats from our neighbors." 54 Another step backward taken by the government of the Tungku was to postpone the formation of Malaysia from August 31 to September 14 pending the result of the mission of the UN team. The nine-man UN team headed by American Laurence V. Michaelmore was "very balanced." 55 He had 17 years' experience of working with the UN. The Philippines and Indonesia sent their respective teams. The UN observer team arrived in Singapore before proceeding to Kuching.

On September 13, 1963 the UN Secretary General submitted the findings of the UN teams to the governments of the Philippines, Indonesia and Malaya. The findings showed that the inhabitants of North Borneo and Sarawak agreed to become part of the Federation of Malaysia. The Philippines was not satisfied with the results saying that these did not reflect the true 
feelings of the peoples of both North Bornean territories because of British pressure. ${ }^{56}$ According to one report the UN observers were not present during the early part of the ascertainment and that the questions given were superficial. Indonesia on the other hand considered the formation of Malaysia as a neocolonial creation and refused to recognize the union. The Philippines demanded that a referendum should be held but the Malayan government refused. ${ }^{57}$

Three days later on September 16, 1963 the Federation of Malaysia was inaugurated. The new federation absorbed the two North Bornean territories, Sabah (North Borneo) and Sarawak and the island of Singapore. ${ }^{58}$ While the Manila press mentioned the event and the editorials voiced their greetings, the Philippine government withheld its recognition. Aside from doubting the results of the ascertainment by the UN teams another reason for the non-recognition of Malaysia by the Philippines involved its claim to Sabah. The refusal to recognize Malaysia was described by historian Felipe Agoncillo as President Macapagal's way to force Malaysia recognize the Philippine claim to North Borneo The Indonesians meanwhile were openly hostile and increased its program of Konfrontasi which would last for several years. ${ }^{59}$

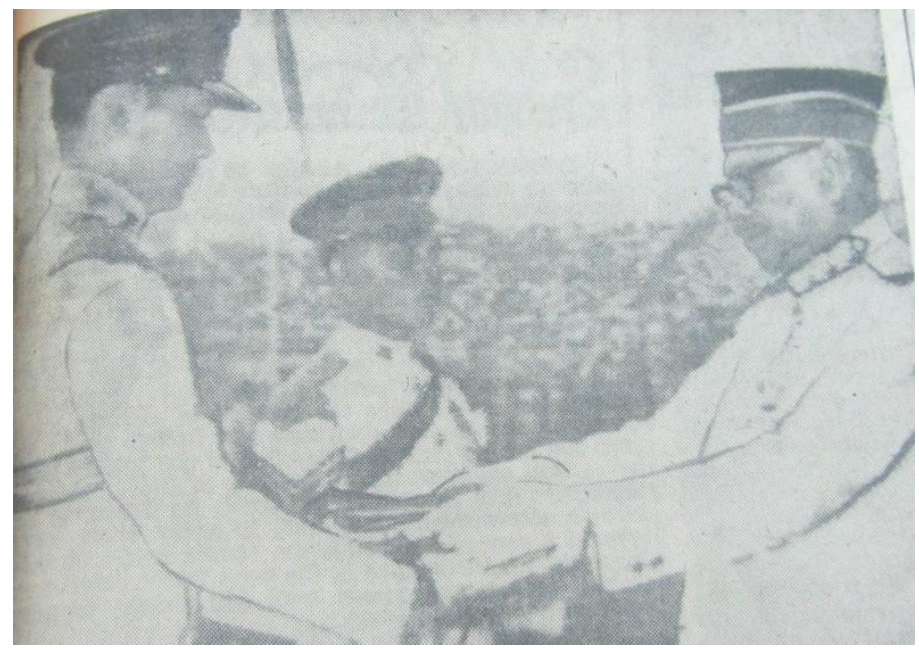

Birth of the Federation of Malaysia: Prime Minister Tungku Abdul Rahman turns over the flag of the Federation of Malaysia during the inaugural rites in Kuala Lumpur on September 16, 1963 (Manila Daily Bulletin) 


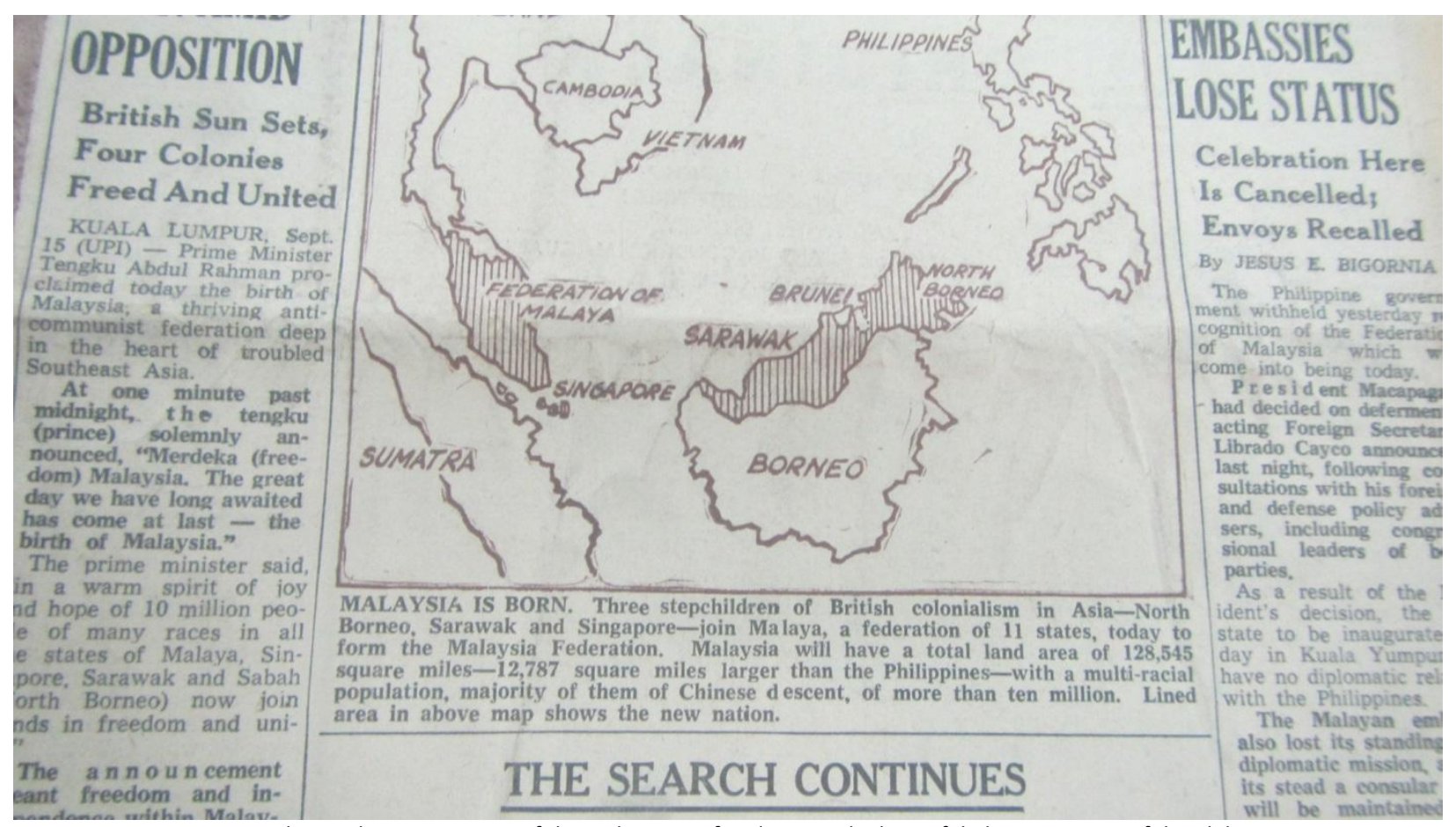

Front page newspaper articles on the inauguration of the Federation of Malaysia . The loss of diplomatic status of the Philippine and Malayan embassies following Malaysia's inauguration is discussed in the article on the left side of the page. (Manila Bulletin)

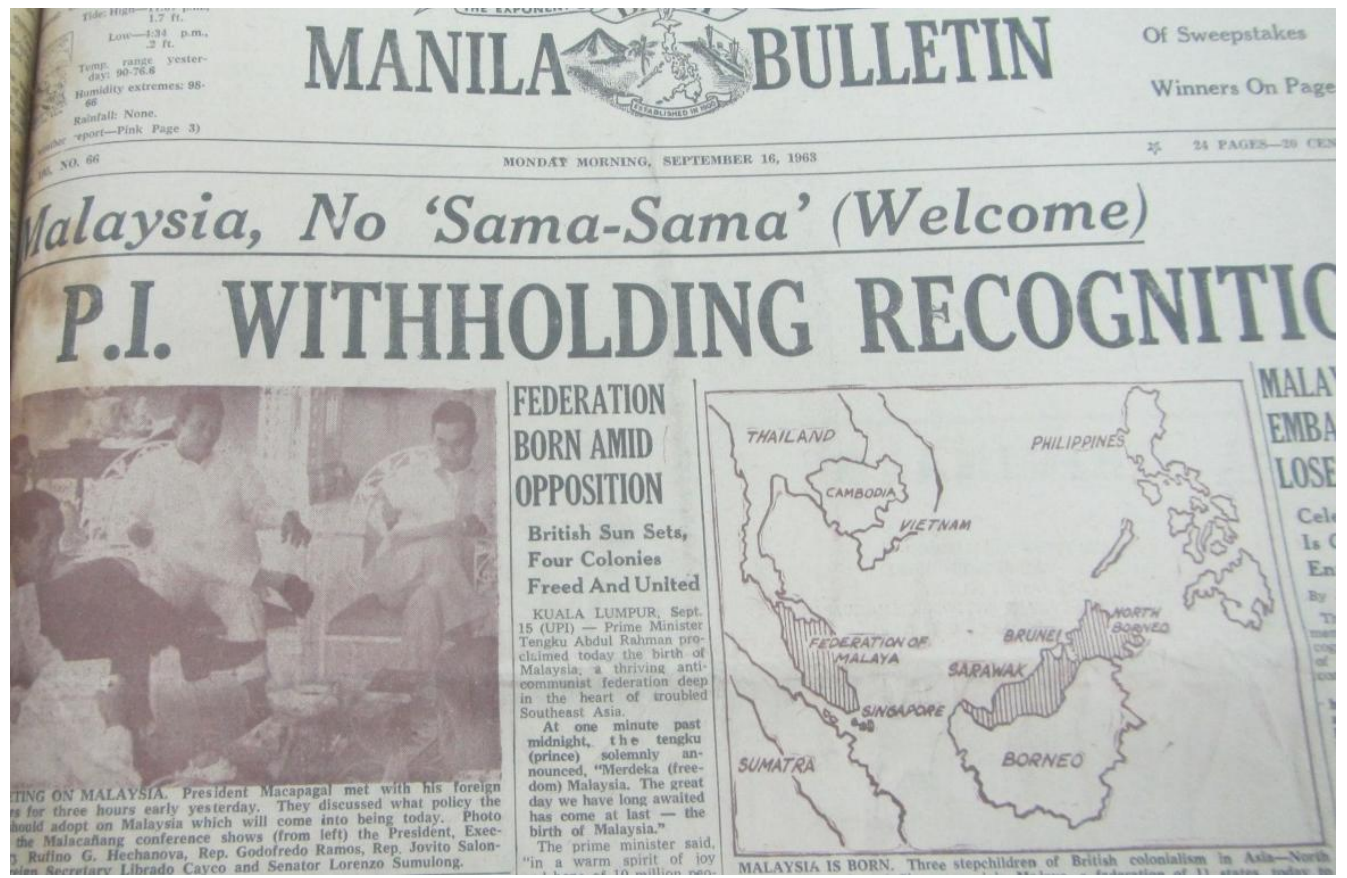

The banner story however was the withholdingof official recognition of the Federation of Malaysia. (ManilaDaily Bulletin)

With the deferment of recognition of Malaysia, the embassy of the Philippines lost its diplomatic status. Celebrations by the Malaysian and Philippine embassies in both Manila and 
Kuala Lumpur were cancelled. On the same day the Philippine ambassador was recalled to Manila. According to the Foreign Office in Manila, the Philippine ambassadors YussupAbubakar was being recalled for consultations and help draft the Philippine position on Malaysia.

Malaysian officials asked the Philippine and Indonesian officials to explain why both countries have not recognized the new union. Speaking five hours after the inauguration of Malaysia, Foreign Minister GhazaliShafie asked the ambassadors of both countries clarification whether they are breaking off diplomatic relations. "I am completely befuddled at the moment," Ghazali said. Regarding the possible breakup of MAPHILINDO, Ghazali said: "It is a tremendous disappointment, we never geared to the possibility of Indonesia breaking off diplomatic relations. "As the Philippine ambassador Abubakar left for Manila, the Malaysian Ambassador Zaiton Ibrahim said during a planeside interview: "I deeply regret that the Philippine government has not extended recognition to the Federation of Malaysia." He added however: "I am confident that the desired recognition be given soon, so that I may be able to return." 60

Meanwhile students in Manila and Jakarta began demonstrations at the embassies of Malaysia in the Philippines and Indonesia. Newspaper columns on the other hand called for restraint and sobriety. In its editorial on the first Malaysia Day, the Manila Daily Bulletin wrote: 61

"In the long and hard days that lay ahead the new state of Malaysia and her neighbors now at odds, much can be gained by proceeding cautiously and sobriety toward reestablishment of cordial relations. Malaysia for example should consider the advisability of giving continuity to foreign policies of the old Malayan government, among which is one according sympathetic treatment to Philippine claims, in succession to those of the Sultanate of Sulu on North Borneo.

There is no denying sympathy and good wishes for Malaysia in non-official quarters. There is no reason for thinking these sentiments will not eventually shared by our government, not alone because of geographical propinquity are inescapable but also blood is thicker than water and peoples of the Malay Race cannot be forever be divided. Malaysia is destined to play an increasingly vital role in reuniting all Malay peoples into one big happy family linked by indissoluble ties of true brotherhood."

In the Philippine Congress, legislators urged the government to recognize the new Malaysian Federation. Macapagal for his part awaited the report from the Foreign Affairs Department. $^{62}$ Later the Philippines requested that its embassy in Kuala Lumpur be downgraded into a consulate. This request was turned down by the Malaysian government. This move was unprecedented in Philippine diplomatic history. No less than the Tungku himself complained about the Philippine suggestion saying it was insulting and uncalled for. He said "It is like living in your house and then I am suddenly told to move into the servants' quarters." He added "I have made myself appear rather small in their yes. I went begging on my knees for peace I have done everything for peace; I cannot be expected to do any more." 63 


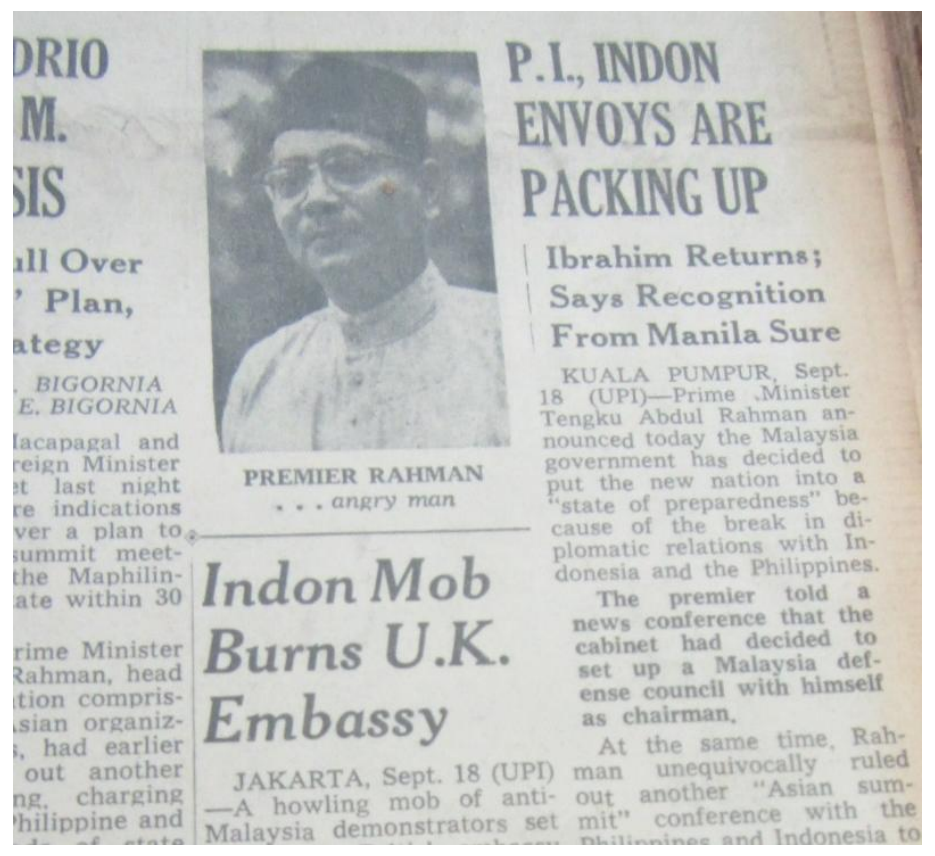

Prime Minister Abdul Rahman on the Philippine request to downgrade its relations with Malaysia from an embassy to a consulate: "It is like living in your house and then I am suddenly told to move into the servants' quarters."

The page also shows the closures of the Philippine and Indonesian embassies in Kuala Lumpur and the burning of the British embassy in Jakarta for UK's support for the formation of Malaysia. (Manila Daily Bulletin)

The Malaysian government then severed diplomatic relations with the Philippines. The Malaysian officials assured the Philippines that the severance of relations was done "with a heavy heart and it was "last ditch effort" to protect the dignity of the Malaysian government. ${ }^{64}$ They put up the defense that the Tungku had no choice but to cut off relations because of the recall of Manila of its envoy. According to the Philippine government recognition of Malaysia was necessary because of Malaya ceased to exist and Malaysia, a new state, has come into being. Among all nations only Indonesia shared this view of the Philippines.

The Malaysians for their part said there exists no precedent for the Indonesian decision not to recognize Malaysia and for the Philippines to withhold recognition of the new Federation. Apparently the pullout of ambassadors meant that the governments concerned had indicated their desire to sever diplomatic relations with Malaysia.

In explaining the Malaysian position Foreign Minister Ghazali said that the Malaysian Constitution provided for the admission of new states to the Federation. The Constitution was amended by an Act of Parliament providing for the inclusion of the new states of Sabah, Sarawak and Singapore. Ghazali also stressed that there is no need for the extension of recognition by any nation to the state of Malaysia and there will be no representation of credentials by foreign envoys accredited by Malaysia. Only new envoys will be accredited by Malaysia instead of Malaya in line with the change of name of the country. ${ }^{65} \mathrm{With}$ the severance of Philippine-Malaysian relations, the Philippine embassy in Kuala Lumpur closed shop. 


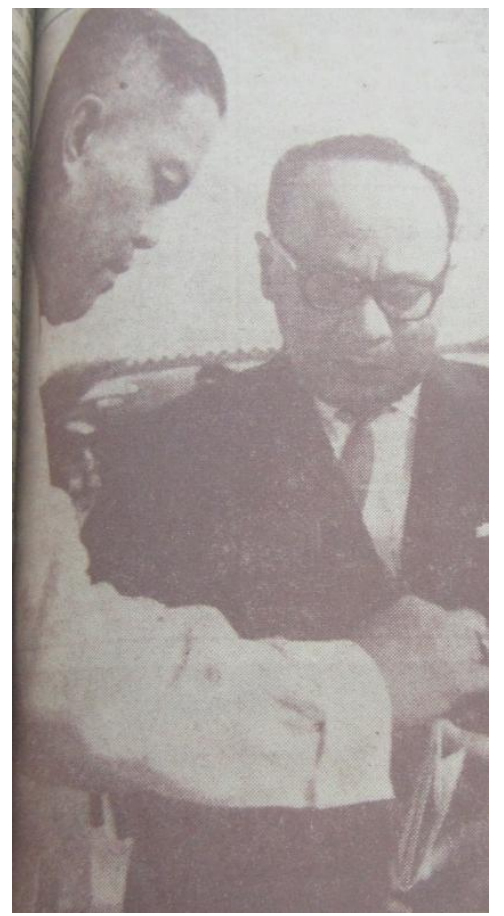

Philippine ambassador YussupAbubakar arrives at the Manila International Airport after being recalled from his post in Kuala Lumpur.

(Manila Daily Bulletin)

As the Philippine government was plotting its next moves.Macapagal was assailed for breaking his vow to the Tungku in promising to work out the differences in a conciliatory and peaceful manner. ${ }^{66}$ The diplomatic crisis clearly shook MAPHILINDO to its very foundations. The Macapagal administration was chided for being a tool of the Indonesians. Even the Tungku was convinced as it was said that Sukarno won over Macapagal by lavishing praise on him as a leading statesman in Asia. Outside of the Philippines the Philippines gained a sort of notoriety in Singapore and in Malaya that was associated with Bung Karno (Brother Sukarno) and the Konfrontasi. There was growing uneasiness among opinion leaders and government officials about the Philippines' growing partiality towards Indonesia. ${ }^{67}$

Malaysian officials in Kuala Lumpur also saw that Manila lacked concern regarding Indonesian- supported raids in Sarawak, North Borneo and fifth column activities in the rest of Malaysia. In an issue of the Manila Daily Bulletin's Listening Post column it commented that the Indonesian press tried to give the impression that the anti-communist Filipinos aligned themselves with neutralist Indonesians against anti-red Malaysians. This was clearly red-baiting on the part of the Manila media which avoids the issue of strained relations with Malaysia. But to build its image as an impartial peacemaker the Philippines must stay clear of Indonesia's Konfrontasi with Malaysia. ${ }^{68}$

For the rest of the Macapagal administration MAPHILINDO and Philippine-Malaysian relations remained in a limbo. To save the organization Japan urged the leaders of the three countries to meet to thresh out their differences. Prime Minister Hayato Ikeda made this suggestion during his four day visit to Manila on September 26, $1963 .{ }^{69}$ There were proposals in 1964 to expand MAPHILINDO to include non-Malay countries. With the inauguration of the 
new Marcos administration in 1965, President Ferdinand Marcos promised to reestablish relations with Malaysia. It received the assurance from Malaysia that it was not averse to elevating the Sabah issue to the World Court or to submitting it to peaceful negotiations or arbitration. On June 3, 1966, the Philippines and Malaysia resumed diplomatic relations. MAPHILINDO, on the other hand remained dormant until it was superseded by the Association of Southeast Asian Nations (ASEAN) on August 8, 1967. ${ }^{70}$

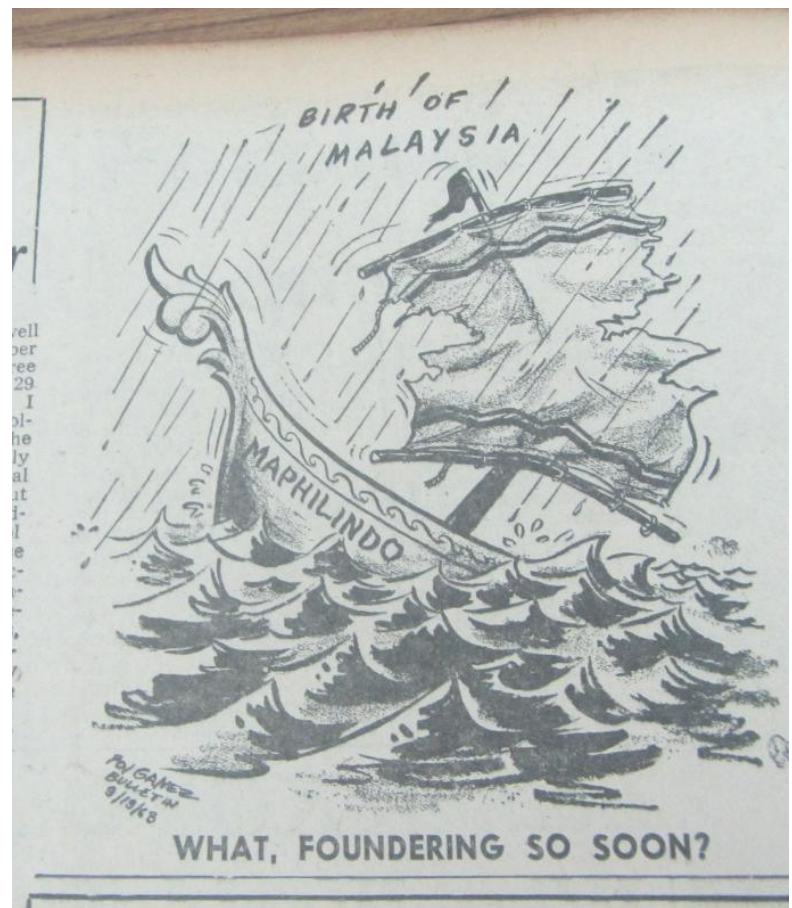

The stillbirth of Maphilindo as seen in this editorial cartoon of the Manila Daily Bulletin on September 19, 1963.

\section{Analysis and Conclusions}

The road to the formation of the MAPHILINDO has its origins to the dreams of heroes and martyrs from Jose Rizal, ApolinarioMabini, WenceslaoVinzons to Tan Melaka, Muhammad Yamin and Ibrahim Ya'acob. It was part of the anti-colonial struggle and the aspiration to regain the free Malay world which existed before the coming of western colonizers. The visions of Rizal and other Malay irredentists advocated the revival of the glory of the days of the Sri Vijaya and the Majapahit empires where the kingdoms and subkingdoms of what is now Indonesia, Malaysia, Brunei and the Philippines, freely traded, maintained very cordial relations and helped each other during times of crisis. It should be remembered that peoples in the region freely travelled and lived in the various islands that comprised Island Southeast Asia. Even the rulers such as those of Johore, Palembang, Manila, Jolo and Palawan were blood brothers. This knowledge of the glorious past was appreciated by individuals like Rizal and latter advocates like Vinzons, Yamin, Melaka and Ibrahim. According to them western colonialism destroyed this glorious past and created artificial boundaries in the region. Colonialism also changed the character and mentality of its inhabitants. The Hispanization and the Christianization of the Philippines for example created an amnesia of the great link with the Filipinos' Malay brothers and their regional heritage. During their time thinkers from Rizal to Melaka tried to revive the 
consciousness of the glorious past of the Malay nation. By doing so they were undermining the colonial establishment and they were persecuted for doing so. The independence of the countries of the Philippines, Indonesia and Malaysia following the end of the Second World War left the region divided according to colonial lines. Even as independent countries these nations were actually neocolonial creations still bound to their old masters. The leaders of the newlyindependent nations namely the Philippines, Malaysia and Indonesia should have proposed the union right after breaking their colonial bonds.

When the MAPHILINDO was created in 1963, it was an opportunity to recreate this Malay Union. However the intention that formed it was wrong from the start. It was a wrong solution to a wrong problem. President Macapagal proposed the union as a way of solving the Philippine failure to resolve the Philippine claim to Sabah. In forming the MAPHILINDO the Sabah claim should have been set aside and its place should be the more important business of forming the Malay Union and what would be its responsibilities and extent of its powers over the lives of 40 people Malay people. There will be questions about the soon to be formed Malay Union: Will the Malay Union be like the United States like a federal union? Will it be centrally controlled like the former Soviet Union? Will it be just a more loose confederation of states like the European Union? Or will it be just an association limited to economic and cultural matters, much like today's ASEAN? These possibilities were never fully explored as the MAPHILINDO died as soon as the ink on the document forming it had dried up.

When the MAPHILINDO was formed under the Manila Accord, MAPHILINDO appeared to be a loose confederation of states whose people were of Malay origin. It was nowhere near the Malay world once exemplified by the Sri Vijaya and the Majapahit empires or the revived Malay world envisioned by people from Rizal to Ibrahim. The three nations of Malaya, the Philippines and Indonesia will still retain their respective national independence and sovereignty. Whatever it may decide will be through periodic but frequent consultations. The creation of the MAPHILINDO may provide for some economic provisions such as free trade among its members and some cultural and educational exchanges. Though it may be a loose confederation, the formation of the MAPHILINDO was a good start and it may lead eventually to a political and economic union in the likes of the United States or the European Union.

The obstacles to the existence of MAPHILINDO were formidable and serious. The first was the national interests of its members particularly the Philippines and Malaysia. The Philippines believed that it had the rightful claim to North Borneo or Sabah. To the Malayans for their part they believed that the formation of the Federation of Malaysia was achieved after the inhabitants of Sarawak and Sabah exercised their free will and decided to join this new federation. Also the Malayans believed that they were the rightful heirs to this part of the former British Empire. The dispute of Malaysia and the Philippines over Sabah was the bone of contention which affected not only the MAPHILINDO but Philippine-Malaysian relations as well.

The second great obstacle was the issue of neocolonialism. The Manila Accord was hailed by President Macapagal as a declaration of independence from the great powers. This was a great illusion as Malaya and the Philippines are still bound by contracts and agreements with their former colonizers. The Philippines at that time hosted American military bases on various parts of the country. Its foreign policy followed the dictates of the United States especially in dealing with socialist countries. On the economic front American companies at that time were exploiting the country's resources in exchange for World War II rehabilitation assistance. Malaya too was affected by neocolonialism. It is part of the British Commonwealth of Nations 
which professes close ties with its former colonizer, the United Kingdom. Malaya it hosted a big military base of the British in Singapore and it is also bound by various economic and political agreements with the United Kingdom. Both the Philippines and Malaya were fighting communism and were dependent on their former colonizers for political and military support. Indonesia for its part professed a neutralist stance and initially avoided sided with the Western bloc and the Socialist bloc. However it was slowly drifting towards the influence of the Soviet/Socialist bloc. Indonesia was strongly opposed to the formation of the Federation of Malaysia and considered it as a neocolonial creation meant to extend the influence of the United Kingdom beyond 1963. The inclusion of the two north Bornean territories of Sarawak and Sabah was a creation of the British. The opposition to neocolonialism was the reason for the Konfrontasi and the "Crush Malaysia Campaign."

While Indonesia opposed the formation of the Federation of Malaysia, it saw itself as the nucleus of the future Malay Union that will someday absorb Malaya, Singapore, Sarawak, Sabah and later the Philippines. This possibility was opposed by United Kingdom and its Commonwealth allies which sent troops and equipment to defeat Sukarno's Konfrontasi campaign. When the Philippines supported Indonesia by withholding recognition for Malaysia, its neocolonial master the United States, distanced itself from the Philippines.

Certain ethnic groups especially the Chinese opposed the MAPHILINDO. Singapore Prime Minister Lee Kuan Yew said that it is a racial concept and he said that Peoples Action Party will fight it. $^{71}$ In Penang the President of the State Chinese Association Koh Sin Hock suggested that MAPHILINDO should be scrapped. He said "It cannot be a reality if a member is determined to crush and destroy another. The sooner it is scrapped, the better." ${ }^{, 72}$ Some Malays also opposed MAPHILINDO as the Indonesian Communist Party called for the immediate recognition of the Government of North Kalimantan which was proclaimed by Brunei rebel A.M. Azhari. In a lengthy report written by the chairman of the party D.N. Aidit he dismissed the idea of forming the MAPHILINDO because of the fundamental differences between Malaysia and Indonesia. ${ }^{73}$ Other countries were not thrilled with the formation of the MAPHILINDO. Thai Foreign Minister ThanatKhoman expressed his misgivings with MAPHILINDO because it was "obsolete" because it emphasized racial and ethnic aspects among its partners. He said Asia is cosmopolitan and we come from various cultural backgrounds. ${ }^{74}$

On the other hand there were groups calling for the restoration of the MAPHILINDO. In Malaysia, the President of the Pan Malaysian Islamic Party, Dr. BurhanuddinAlhemy urged Malaysia, Indonesia and the Philippines to revive the MAPHILINDO as a step towards a settlement of the dispute between Malaysia and Indonesia. ${ }^{75}$ The restoration of the three-nation organization will help promote stability in the region. In the Philippines the government mulled the possibility of reviving MAPHILINDO in 1965. Filipino legislators especially Deputy Speaker of the House of Representatives SalipadaPendatun said that MAPHILINDO and ASA (Association of South Asia) must continue to exist. He said that "My country has high hopes that the problems confronting Malaysia, Indonesia and the Philippines can be resolved." 76 For the Indonesians, President Suharto stated that he would like his country "to unite with the Malay race and other friendly neighboring countries." He stated that Malaysians are free to rejoin the MAPHILINDO. ${ }^{77}$ On the other hand the Malaysians considered the MAPHILINDO "dead and buried." Malaysian Deputy Prime Minister Tun Abdul Razak said, that as far as the Malaysian government is concerned, the MAPHILINDO concept is dead and buried. ${ }^{78}$ Razak earlier accused the Philippines and Indonesia of violating the Manila Agreement and that he was willing to lay 
his cards on the table that the two countries violated the accord which formed the MAPHILINDO. ${ }^{79}$

Other countries hoped that the three countries would restore MAPHILINDO. British Prime Minister Sir Alec Douglas-Home shared a view that the final settlement of the MalaysiaIndonesia problem would be covered broadly by Maphilindo, an economic and political and perhaps a defense plan covering the security of Malaysia. ${ }^{80}$ Other countries like Australia and New Zealand shared the same view. Malaysia for its part declined to having a part in a new alliance. On December 13, 1964, the Malaysian Ministry of External Affairs turned down an invitation to discuss the formation of a new Asian cultural, economic, political and defense alliance. $^{81}$ At that time there was talk that the Philippines and Malaysia may be asked to join Indonesia to form an anti-communist alliance intended to block Chinese Communist influence in Southeast Asia. ${ }^{82}$

Despite the serious problems facing the organization Philippine officials remained hopeful for the restoration of the relations between the Philippines and Malaysia. Foreign Secretary Lopez said that "MAPHILINDO is a great idea that never dies" and we look forward to the resumption of discussions and consultations with outMaphilindo partners (Malaysia and Indonesia). ${ }^{83}$ With the refusal of Malaysia to rejoin the organization at that time, talks were held to have other countries instead. In January 1964 Cambodia said it wants to join MAPHILINDO. President Sukarno and President Macapagal suggested to have other countries like Thailand and Burma join it. $^{84}$

When the new administration of Ferdinand E. Marcos took over in the Philippines in December 1965, President Marcos proposed a new organization that would go beyond the Association of South Asia (ASA) and the MAPHILINDO. He proposed that even non-Malay countries should become members of this new alliance. ${ }^{85}$ Apparently this was a response to Thailand's rather unfavorable reaction to the MAPHILINDO's creation and the willingness of non-Malay countries like Cambodia to join it. The new organization must be encompassing beyond ethnic grounds and should embody the regional aspirations of like-minded nations in the Southeast Asian region. In January 1964 Thai Senator Thuraisingham called for the formation of a Pacific Asian Treaty Organization (PATO) which would include the Maphilindo countries as well as Brunei, Thailand, Australia and New Zealand. ${ }^{86}$ Within a few years' time the regional grouping of Southeast Asian nations which is now known as the Association of Southeast Asian Nations (ASEAN). Presently ASEAN comprises ten Southeast Asian states which includes the Philippines, Malaysia, Indonesia, Thailand, Singapore, Brunei, Cambodia, Vietnam, Laos and Myanmar. The organization aimed to help in the economic growth and social progress among its members as well as to resolve disputes peacefully.

In its very short existence, MAPHILINDO never had the chance of effecting the expected cultural, social and economic exchanges and cooperation because it was surrounded by purely political and parochial issues namely the Sabah claim and Indonesia'sKonfrontasi with Malaysia. Had these obstacles been overcome, it would have contributed greatly to the economic progress, better cultural understanding and social unity of the region. Its benefits would have influenced the peoples of the three countries and improved their general welfare.

Nevertheless the formation of MAPHILINDO in 1963 that the people of Malay stock showed they can easily work together despite serious differences. This attitude supersedes organization itself. The leaders and peoples of the three countries showed uncommon patience, diligence and a willingness to work together to attain a higher goal. This can be seen in the attitude of the leaders and officials in solving their problems. Credit should be given to the 
Prime Minister of Malaysia Tungku Abdul Rahman for his prudence in agreeing to postpone the formation of Malaysia from August 31 to September 16 in order to await the results of the ascertainment report from the United Nations. Equal recognition should also be given to Sukarno to agreeing to set aside his Konfrontasi in 1963 and have the dispute between Malaya and Indonesia to be mediated by Macapagal in Tokyo. The mediation led to the signing of the Manila Accord which in turn led to the formation of MAPHILINDO. It showed that the leaders of the three nations were capable of setting aside their national and parochial interests for the sake of a higher purpose- the attainment of Malay unity. The latter insistence on individual national interests however by the three states MAPHILINDO to fail.

Even when conflict threatened the three countries, all parties were willing allow the issue to cool down, practice restraint and wait for an opportunity to talk sensibly. When Malaysia severed diplomatic ties with the Philippines it was reported that Malaysian Prime Minister Tungku Abdul Rahman who was said to have grave cause to sever relations with the Philippines said he had not lost faith in the majority of the Filipino people and their feelings for Malaysia. The Tungku, as he was called, showed this concern during the first emergency meeting of the Malaysian cabinet where he asked that the Philippines should be removed in the government's declaration of preparedness against possible armed Indonesian action in Malaysia especially in Sabah and in Sarawak. ${ }^{87}$ Later in 1965 the Tungku held the view "that diplomatic ties with Manila could be established irrespective of any problems that exist between the two countries." 88

Malaysia always kept the door open for backdoor and backroom negotiations whenever there is a deadlock in any negotiation. During the time there were no official diplomatic relations between Malaysia and the Philippines until these were restored in 1966 under the administration of President Marcos it was reported that talks were proceeding through the backdoor process.

Recently (during 2010 and few years thereafter) Malaysia played an important role in working for the peaceful solution towards the separatist rebellion in southern Philippines. It served as a mediator between the separatist Moro Islamic Liberation Front (MILF) and the Philippine government. The backdoor approach also worked with Indonesia. The Indonesian and Philippine representatives working quietly in the background peacefully resolved their border issues regarding the boundary in the Celebes Sea in June 2014. Indonesia also played a part in the resolution of the conflict in Southern Philippines. Regarding the relations with Indonesia and Malaysia, the two nations eventually came to terms following the Konfrontasi and both countries now respect each other's sovereignty. In any negotiation with the Malaysians and Indonesians there is always room for backdoor and backroom discussions to resolve problems where talks on the official level were deadlocked or rendered stale.

The key to the camaraderie between the three nations is the Malay blood that runs through the veins of the peoples of the Philippines, Malaysia and Indonesia. The peoples of these islands are blood brothers that not even parochial concerns and geographical divisions can separate the fraternal bonds. Though MAPHILINDO is no more and is superseded by an organization which includes non-Malay peoples now comprised by the ASEAN, the people of Indonesia, Malaysia and the Philippines remain as partners and friends working towards a common future. 


\section{Notes}

1 Arnold Brackman,Southeast Asia's Second Front- The Power Struggle in the Malay Archipelago, London: Pall Mall Press, 1966, pp. 178-179.

2 Aileen Baviera (Ed), Philippine External Relations A Centennial Vista, Manila: Foreign Service Institute, 1999, p. 336.

3 Ibid., p. 135.

4 This essay was Sobre la Indolencia de los Filipinos (About the Laziness of the Filipinos), published in the propaganda newspaper La Solidaridad. In this essay Rizal argued that the perceived laziness of the Filipinos was caused by oppressive colonial practices and that before the coming of the western colonizers, the natives of the Philippines obtained only the amount of goods that they would need and they conducted commerce freely in the Southeast Asian regions and beyond. See, Jose Rizal, Political and Historical Writings, Manila: National Heroes Commission, 1962, pp. 227-265.

5 One of Rizal's contemporaries was Pedro Paterno who made a study of the ancient language of the natives of the Philippines and compared with the Malay language. He was suspected of using his findings to foment sedition against the Spanish government.For further reading see Pedro Paterno, Ninay, The First Filipino Novel and El Pacto de Biak naBato, Manila: National Historical Commission, 2005, pp.1-3.

$6 \quad$ Ibid., p. 136.

7 ApolinarioMabini, "What is the Real Mission of the Philippine Revolution?" In: The Philippine Revolution, Vol. II, Manila:Bureau of Printing, 1931, p. 56.

8 Cesar AdibMajul, Mabini Revolutionary, Manila: 1964, p. 204.

9 Baviera, ibid., p. 137.

10 Ibid.

11 Ibid.

12 Austin C. Craig and Conrado Benitez (Eds), Prehistoric Civilization in the Philippines, Manila: Philippine Education Company, 1916, pp.79-117.The Malaysia Furlong was referring to was the East Indian archipelago consisting of Sumatra, Java, the Celebes, Borneo, Moluccas and the islands of the Philippines.

13 Zeus, A. Salazar, The Malayan Connection AngPilipinassaDuniaMelayu, Quezon City: Palimbaganng Lahi, 1998, p. 150.

14 Rosihan Anwar, "Rizal's Name in Indonesia. Proceedings of the International Congress on Rizal, 4-8, December 1961, Manila: 1962, pp. 298-303.

15 RanavalonaVinzons-Gaite, Wenceslao Q. Vinzons A Youth to Remember. (The Author: 1977), pp. 5-8.Mrs. Gaite was the daughter of Vinzons. Her father's admiration for the Malay race can be reflected by the name of his daughter, Ranavalona. Ranavalona was named after Ranavalona I who was the sovereign of Madagascar in the $19^{\text {th }}$ century and fought off French attempts to colonize the island. -avv. .

16 Suradji, D.Indonesian-Philippine Political Relations: An Analysis and Evaluation. Unpublished Ph.D. Dissertation, University of Santo Tomas Graduate School, 1983. pp 136-137.

17 “Malaya Reborn”- avSee Baviera, p. 138.

18 Gaite, ibid., pp. 8-9. 
19 Greg Poulgrain,The Genesis of the Konfrontasi Malaysia, Brunei and Indonesia, Petaling Jaya: Strategic Information and Research Development Centre, 2014, p. 31.

Baviera, p. 138.

Ibid.

Salazar, pp. 127-128.

Gaite, p. 8.

Ibid.

Brackman, p. 51.

Suradji,p. 3.

Poulgrain, p. 31.

Baviera, p. 98.

Salazar, pp. 152-153.

Ibid., p. 153.

Gordon P. Means, The Malayan Politics, London: University of London, 1970, p. 23.

Ibid.

Ibid., pp. 45-46.

Baviera, p. 161.

Ibid.

Baviera, p. 162.

Ibid.

Since 1946 according to Macapagal who presided over the return of the Turtle Islands to the Philippines, , found documents that North Borneo was leased, not ceded by the Sultan of Sulu to two European adventurers, Baron de Overbeck of Austria and Alfred Dent of England in 1875. Since then the government was negotiating with the British to return the territory to the Philippines as the heirs of the Sultan allowed the government of the Philippines to represent them in the negotiations. -avv .

See Quentin Reynolds and GeoffreyBocca, Macapagal The Incorruptible, New York: DavidMcKay Co., Inc 1965, pp. 74-78.

James Ongkil,The Borneo Response to Malaysia 1961-1963. (Singapore: Donald More Press1967), Ongkil, pp. 80-112.

Baviera,ibid., p. 162.

Ibid.

"Maphilindo Seen as Third Force," The Straits Times, August 14, 1963, p. 12, Reel No. NL 12150, http://eresources.nlb.gov.sg/newspaperdigitized.Accessed August 19, 2015.

"Maphilindo is not Against the Chinese in Malaysia- Tan," The Straits Times, August 7, 1963, p. 18. Microfilm Reel No.NL 12182, http://eresources.nlb.gov.sg/newspaperdigitized.Accessed August 19, 2015. TeodoroAgoncillo, History of the Filipino People, Garotech: Quezon City 1990, p. 540. Speaking in retrospect on July 5, 1964 Singapore Prime Minister Lee Kuan Yew explained why the People's Action Party (PAP) was against the MAPHILINDO. Speaking before a multiracial audience at Kampong Kapor, Lee who was the Secretary General of the PAP said, "We are not afraid of MAPHILINDO. We will fight it because it is a racial concept. It will definitely break up Malaysia if the idea materializes. 
See: "Premier on MAPHILINDO Concept," Straits Times, July 6, 1964, p. 1, Microfilm Reel NL 12150, http://eresources.nlb.gov.sg/newspaperdigitized. Accessed August 19, 2015.

"Macapagal Says it: Maphilindo not Racial," The Straits Times. August 23, 1963, p.

2.Microfilm Reel No.NL 12147, http://eresources.nlb.gov.sg/newspaperdigitized.Accessed August 19, 2015.

"Maphilindo is an Expanding Group, says Lopez," The Straits Times, September 12, 1963,

p. 2, http://eresources.nlb.gov.sg/newspaperdigitized. Accessed August 19, 2015.

"MAPHILINDO could be Dangerous," The Straits Times, December 3, 1963, p. 1, Microfilm Reel No. 12152, http://eresources.nlb.gov.sg/newspaperdigitized. Accessed August 19, 2015.

“Three Nations Ink Manila Accord."Manila Chronicle, Manila Chronicle. August 6, 1963, pp. 1,5 .

Agoncillo, Ibid.Also refer to: Manila Accord published in Manila Chronicle, August 6, 1963.

50 “Heads of Three States Issue Joint Communiqué," Manila Chronicle, August 6, 1963, p. 5.

Oscar Villadolid, "P.I., Indonesia Give Support to Malaysia; Confrontation Policy

Dropped; Maphilindo Set," Manila Daily Bulletin, August 5, 1963, p. 1.

"Accord Hailed as Second Declaration of Independence- Macapagal. "Manila Daily

Bulletin, August 6, 1963, p. p. 2.

53 Ceasar Espiritu, "MAPHILINDO Can Create Confederation of Visions," Manila Daily

Bulletin, p. 1.August 6, 1963.

Malaya Accepts Delay of Malaysia Formation" Manila Daily Bulletin, August 15, 1963.

Also: Manila Daily Bulletin, August 25, 1963, p. 2.

Ibid.

Agoncillo, p. 540. .

Oscar Villadolid, "Summit Seeking UN Action on Malaysia: Referendum Sought but Malaya Hedges," ManilaDaily Bulletin, August 1, 1963 , p. 1.

"Malaya Combines with Singapore so it will not Become an Asian Cuba," Manila Daily

Bulletin, September 17, 1963.

Agoncillo, Ibid.

“Malay Bids P.I. Indon to Explain,” Manila Daily Bulletin, September 18, 1963, p. 5.

Editorial, Manila Daily Bulletin, September 16, 1963.

62 “P.I. to Recognize New Malaysia Federation," Manila Daily Bulletin, September 17, 1963, p. 1.

Oscar Villadolid, "Malaysia Wonders About P.I. Action," Manila Daily Bulletin, September 23, 1963, pp. 1, 6 .

"Malaysia Breaks Ties to Keep Honor, Dignity," Manila Daily Bulletin, September 17, 1963, p. 1.

Oscar Villadolid, “The End of MAPHILINDO?” The Listening Post, Manila Daily

Bulletin, September 23, 1963, p. 6.

Oscar Villadolid, “Following Brother Sukarno?”,Manila Daily Bulletin, September 23

1963, p. 1.

67 Oscar Villadolid, “ P.I. Blurs Image over Malaysia,” Manila Daily Bulletin, September 20, 1963, p.1. 
68

69

69 "Japanese PM Urges MAPHILINDO Leaders to Meet," The Straits Times, September 27, 1963, p. 1, Microfilm Reel No. NL12149,

http://eresources.nlb.gov.sg/newspaperdigitized.Accessed August 19, 2015.

70 Baviera, ibid.,p. 165.

71 "Premier on MAPHILINDO Concept," Straits Times, July 6, 1964, p. 1. Ibid.

72 "Maphilindo is a Myth," The Straits Times, p. 8. Microfilm Reel NL12149_10.

http://eresources.nlb.gov.sg/newspaperdigitized. Accessed August 19, 2015.

73

"Aidit's Cards on Table," The Straits Times, December 27, 1963, p. 1. Microfilm Reel No. 9794. Japanese PM Urges MAPHILINDO Leaders to Meet," The Straits Times, September 27, 1963, p. 1, Microfilm Reel No. NL12149, http://eresources.nlb.gov.sg/newspaperdigitized.Accessed August 19, 2015.

"MAPHILINDO Too Racial" - Thanat.The Straits Times.January 4, 1966, p. 16, Microfilm Reel No. NL 12177, http://eresources.nlb.gov.sg/newspaperdigitized. Accessed August 19, 2015.

"MAPHILINDO The Answer- PMIP," The Straits Times, December 9, 1964, p. 12.

Microfilm Reel No.NL 12160.http://eresources.nlb.gov.sg/newspaperdigitized. Accessed August 19, 2015. "MAPHILINDO and ASA Must Continue to Exis http://eresources.nlb.gov.sg/newspaperdigitized.Accessed August 19, 2015. "Suharto: We Like to Unite with Malay Race and Other Countries," The Straits Times, August 30, 1966, p. 2. Microfilm Reel No.NL 12162, http://eresources.nlb.gov.sg/newspaperdigitized. Accessed August 19, 2015

"Maphilindo Dead and Buried," The Straits Times, January 31, 1967, p. 9. Reel No. NL 21289, http://eresources.nlb.gov.sg/newspaperdigitized. Accessed August 19, 2015. "Razak Stands Pat," The Straits Times, November 11, 1963, p. 1. Reel No. 12178, http://eresources.nlb.gov.sg/newspaperdigitized. Accessed August 19, 2015.

When the new regional grouping of the Association of Southeast Asian Nations was about to be formed.Razak again declared, There was no requiem in Parliament because the Maphilindo concept was in fact still-born. It never had life. Malaysia is now committed to the Association of Southeast Asia(ASEAN?); it has the same objectives.

See: "The Outlook for ASA," The Straits Times, February 1, 1967, p. 10, Reel No. 12153, http://eresources.nlb.gov.sg/newspaperdigitized. Accessed August 19, 2015.

“Maphilindo Could Settle the Malaysia Dispute: Home,” The Straits Times, June 19 1964, p. 22, Reel No. NL 12190, http://eresources.nlb.gov.sg/newspaperdigitized.Accessed August 19, 2015.

81 "Malaysia's No to a New Alliance," The Straits Times, December 12, 1964, p. 11, Reel No. NL12169, http://eresources.nlb.gov.sg/newspaperdigitized.Accessed August 19, 2015.

82 "Manila to be Asked to Join Anti-Red Pact?" The Straits Times, October 15, 1966, p. 7, Microfilm Reel No.NL 12164, http://eresources.nlb.gov.sg/newspaperdigitized.Accessed August 19, 2015.

83 MAPHILINDO: A Great Idea Never Dies, Says Lopez," The Straits Times, December 22, 1963, Reel No. NL 12152, http://eresources.nlb.gov.sg/newspaperdigitized.Accessed August 
84 “Cam-Phil-Indo!”The Straits Times, January 12, 1964, p. 1. Microfilm Reel No. 12153, ,http://eresources.nlb.gov.sg/newspaperdigitized. Accessed August 19, 2015.

85 "Marcos Proposes Alliance Beyond ASA, Maphilindo," The Straits Times, July 10, 1966, p. 7, Microfilm Reel No.NL 12182, http://eresources.nlb.gov.sg/newspaperdigitized.Accessed August 19, 2015.

86 "Senator Calls for Pacific Asian Bloc," The Straits Times, January 14, 1964, p. 1, Microfilm Reel No. 12160_16, http://eresources.nlb.gov.sg/newspaperdigitized.Accessed August 19, 2015.

87 Villadolid, Oscar. "Malaysia Wonders About P.I. Action, “ Manila Daily Bulletin, , September 23, 1963, p. 3.

88 "Problems No Bar to Ties with Manila: Tengku," The Straits Times, December 16, 1965, p. 15. Microfilm Reel No.NL12148, http://eresources.nlb.gov.sg/newspaperdigitized.Accessed August 19, 2015.

Appendix No. 1

\section{HEADS OF THREE STATES ISSUE JOINT COMMUNIQUE ${ }^{88}$}

(EDITOR'S NOTE IN VIEW OF THEIR HISTORICAL and transcendental significance the joint communiqué and other important documents ratified by Malaya, Philippines and Indonesia tentatively known as Maphilindo, at their summit meeting just concluded are published in this page.)

The President of the Republic of Indonesia, the President of the Philippines and the Prime Minister of the Federation of Malaya met in Manila from July 30 to August 5, 1963

1. Moved by a sincere desire to solve their common problems in an atmosphere of fraternal understanding, they considered, approved and accepted the Report and Recommendations of the Foreign Ministers of the three countries adopted in Manila on June 11, 1963 thereafter to be known as the Manila Accord.

2. In order to provide guiding principles for the implementation of the Manila Accord, the Heads of Government have issued known as the Manila Declaration, embodying the common aspirations and objectives of the peoples and governments of the three countries.

3. As a result of the consultation, amongst the three Heads of Government in accordance with the Manila Declaration, they have resolved various common problems of common concern.

4. Pursuant to paragraphs 10 and 11 of the Manila Accord the United Nations Secretary General should ascertain prior both the establishment of the Federation of Malaysia the 
wishes of the people of Sabah (North Borneo) and Sarawak within the context of the General Assembly Resolution 1541 (XV) Principle 9 of the Annex, by a fresh approach, , which in the opinion of the Secretary General is necessary to ensure complete compliance with the principle of self-determination within the requirements embodied in Principle 9, taking into consideration:

(i) The recent elections in Sabah (North Borneo) and Sarawak but nevertheless further examining and verifying and satisfying himself as to whether

(a) Malaysia was a major issue, if not the main issue;

(b) Electoral registers were properly complied;

(c) Elections were free and there was no coercion; and

(d) Votes were properly polled and properly counted; and

(ii) The wishes of those who being qualified to vote would have exercised their right of self-determination in the recent elections had it not been for their detention for political activities, imprisonment for political offenses or absence from Sabah (North Borneo) and Sarawak.

5. The Secretary-General will be requested to send working teams to carry out the task set out in paragraph 4.

6. The Federation of Malaya, having undertaken to consult the British Government and the Governments of Sabah (North Borneo) and Sarawak under paragraph 11 of the Manila Accord on behalf of the three Heads of Government, further undertake to request them to cooperate with the Secretary-General and to extend to him the necessary facilities to carry out his task as set out in paragraph 4.

7. In the interest of the countries concerned, the three Heads of Government deem it desirable to send observers to witness the carrying out of the task to be undertaken by the working teams and will use its best endeavours to obtain the cooperation of the British Government and the Governments of Sabah (North Borneo) and Sarawak in furtherance of this purpose.

8. In accordance with paragraph 12 of the Manila Accord, the three Heads of Government decided to request the British Government to agree to seek out a just and expeditious solution to the dispute between the British Government and the Philippine Government concerning Sabah (North Borneo) by means of negotiation, conciliation and arbitration, judicial settlement and other peaceful means of the parties' own choice in conformity with the Charter of the United Nations. The three Heads of Government take cognizance of the position regarding the Philippine claim to Sabah (North Borneo) after the establishment of the Federation of Malaysia as provided under paragraph 12 of the Manila Accord, that is that the inclusion of Sabah (North Borneo) in the Federation of Malaysia does not prejudice either the claim or any right thereunder.

9. Pursuant to paragraphs 6, 7, 8 and 9 of the Manila Accord and the Fifth Principle of the Manila Declaration, that is, that initial steps towards the establishment of Maphilindo by 
holding frequent and regular consultations at all levels to be known as

MushawarahMaphilindo, it is agreed that a National Secretariat fort for Maphilindo affairs and as a first step the respective National Secretariats will consult each other with a view of coordinating and cooperating with each other in the study on the setting up of the necessary machinery for Maphilindo.

10. The three Heads of Government emphasized that the responsibility for the preservation of the national independence of the three countries and of the peace and security in their region primarily in the hands of the governments and peoples concerned, and that the three governments undertake to have close consultations (Mushawarah) among themselves on these matters.

11. The three Heads of Government further agreed that foreign bases- temporary in nature should not be allowed to be used directly or indirectly to subvert the national independence of any of the three countries. In accordance with the principle enunciated in the Bandung Declaration, the three countries will abstain from the use of arrangements of collective defense to serve the particular interests of any of the big powers.

12. President Sukarno and Prime Minister Abdul Rahman express their deep appreciation for the initiative taken by President Macapagal in calling the Summit Conference which, in addition to solving their differences concerning the proposed Federation of Malaysia, resulted in paving the way for the establishment of Maphilindo. The three Heads of Government conclude this Conference which greatly strengthened the fraternal ties which bind their three countries and extended the scope of their cooperation and understanding, with renewed confidence that their governments and peoples will together make a significant contribution to the attainment of a just and enduring peace, stability and prosperity in the region.

Manila, August 5, 1963

Appendix No. 2.

\section{RESOLUTION TO ESTABLISH MAPHILINDO SIGNED BY PRESIDENT MACAPAGAL, PRESIDENT SUKARNO AND PRIME MINISTER TUNGKU ABDUL RAHMAN}

\section{THREE NATIONS INK MANILA ACCORD}

The President of the Republic of Indonesia, the President of the Philippines and the Prime Minister of Federation of Malaya assembled in a Summit Conference in Manila from July 30 to 
August 5, 1963 following the meeting of their Foreign Ministers held in Manila from June 7 to 11, 1963;

Conscious of the historic significance of their coming together for the first time as leaders of sovereign states that have emerged after long struggles from colonial status to independence;

Desiring to achieve better understanding and close cooperation in their endeavor to chart their common future;

Inspired also by the spirit of Asian-African solidarity forged in the Bandung Conference of 1955;

Convinced that their countries, which are bound together by close historical ties of race and culture, share a primary responsibility for the maintenance of the stability and security of the area from subversion in any form or manifestation in order to preserve their respective national identities and to ensure the peaceful development of their respective countries and their regions and aspirations of their peoples and;

Determined to intensify the joint and individual efforts of their countries to secure lasting peace, progress and prosperity for themselves and their neighbors in a world dedicated to freedom and justice

\section{DO HEREBY DECLARE:}

First that they reaffirm their adherence to the principle of equal rights and self-determination of peoples as enunciated in the United Nations Charter and the Bandung Declaration:

Second, that they are determined, in the common interest of their countries, to maintain fraternal cooperation among their peoples in the economic, social and cultural fields in order to promote economic progress and social well-being in the region, and to put an end to the exploitation of man by man and of one nation by another;

Third, that the three nations shall combine their efforts in the common struggle against colonialism and imperialism in all their forms and manifestations and for the eradication of the vestiges of the thereof in the region in particular and the world in general;

Fourth, that the three nations, as new emerging forces in the region, shall cooperate in building a new and better world based on national freedom, social justice and lasting peace; and 
Fifth, that in the context of the joint endeavors of the three nations to achieve the foregoing objectives, they have agreed to take initial steps towards the establishment of Maphilindo by holding frequent and regular consultations at all levels to be known as MushawarahMaphilindo.

Manila, August 3, 1963

(Sgd.) SOEKARNO

President of the Republic of Indonesia

(Sgd.) DiosdadoMacapagal

President of the Philippines

Tunku Abdul Rahman Putra Al Haj

Prime Minister of the Federation of Malaya

Appendix No. 3

\section{MANILA ACCORD ${ }^{88}$}

The governments of the Federation of Malaya, the Republic of Indonesia and the Republic of the Philippines , prompted by their keen and common desire to have a general exchange of views on current problems concerning stability, security, economic development and social progress of the three countries and of the region and upon the initiation of President DiosdadoMacapagal, agreed that a Conference of Ministers of the three countries be held in Manila on $7^{\text {th }}$ June 1963 for the purpose of achieving common understanding and close fraternal cooperation among themselves.

Accordingly, Tun Abdul Razak, Deputy Prime Minister of the Federation of Malaya; Dr. Subandrio, Deputy First Minister/Minister for Foreign Affairs of the Republic of Indonesia; and Honorable Emmanuel Pelaez, Vice President of the Philippines and concurrently Secretary of Foreign AFFAIRS, met in Manila from 7 to 11 June 1963.

2. The deliberations were held in a frank manner and in a most cordial atmosphere in keeping with the spirit of friendship prevailing in the various meetings held between President Sukarno of the Republic of Indonesia, Prime Minister Tunku Abdul Rahman Putra of the Federation of Malaya and President DiosdadoMacapagal. This Ministerial Conference was a manifestation of the determination of the nations in this region to achieve closer cooperation in their endeavor to chart their common future. 
3. The Ministers were of one mind that the three countries share a primary responsibility for the maintenance of the stability and security of the area from subversion in any form or manifestation in order to preserve their respective national identities and to ensure the peaceful development of their respective countries and of their region, in accordance with the ideals and aspirations of their peoples.

4. In the same spirit of common and constructive endeavor, they exchanged views on the proposed Confederation of nations of Malay origin, the proposed federation of Malaysia, the Philippine claim to North Borneo and related problems.

\section{The Macapagal Plan}

5. Recognizing that it is in the common interest of their countries to maintain fraternal relations and to strengthen cooperation among their peoples who are bound together by ties of race and culture, the three Ministers agreed to intensify the joint and individual efforts of their countries to secure lasting peace, progress and prosperity for themselves and for their neighbors.

6. In this context, the three Ministers supported President Macapagal's plan envisaging the grouping of the three nations of Malay origin working together in closest harmony but without surrendering any portion of their sovereignty. This calls for the establishment of the necessary common organs.

7. The three Ministers agreed to take the initial steps towards this ultimate aim by establishing machinery for frequent and regular consultations. The details of such machinery will be further defined. This machinery will enable the three governments to hold regular consultations at all levels to deal with matters of mutual interest and concern consistent with the national, regional and international responsibilities or obligations of each country without prejudice to its sovereignty and independence. The Ministers agreed that their countries will endeavor to achieve close understanding and cooperation in dealing with economic, social and cultural development

8. In order to accelerate the process of growth towards the ultimate establishment of President Macapagal's plan, the Ministers agreed that each country shall set up each own national secretariat. Pending the establishment of a Central Secretariat for the consultative machinery, the National Secretaries should coordinate and cooperate with each other in the fulfillment of their tasks.

9. The Ministers further agreed to recommend that Heads of Government and Foreign Ministers meet at least once a year for the purpose of consultations on matters of importance and common concern.

\section{Malaysia and North Borneo}


10. The Ministers reaffirmed their countries' adherence to the principle of self-determination and for the peoples of non-self-governing territories. In this context, Indonesia and the Philippines stated that they would welcome the formation of Malaysia provided the support of the people of the Borneo territories is ascertain by an independent and impartial authority, the Secretary-General of the United Nations or his representative.

11. The Federation of Malaya expressed appreciation for this attitude of Indonesia and the Philippines and undertook to consult the British Government and the Governments of the Borneo territories with a view to inviting the Secretary-General of the United Nations or his representative to take the necessary steps to ascertain the wishes of the people of those territories.

12. The Philippines made it clear that its position on the inclusion of North Borneo in the Federation of Malaysia is subject to the final outcome of the Philippine claim to North Borneo. The Ministers took note of the Philippine claim and the right of the Philippines to continue to pursue it in accordance with international law and the principle of the pacific settlement of disputes. They agreed that the inclusion of North Borneo in the Federation of Malaysia would not prejudice either the claim or any right thereunder. Moreover, in the context of their close association, the three countries agreed to exert their best efforts to bring the claim to a just and expeditious solution by peaceful means, such as by negotiation, conciliation, arbitration, or judicial settlement as well as other peaceful means of the parties' own choice, in conformity with the Charter of the United Nations and the Bandung Declaration.

13. In particular, considering the close historical ties between the peoples of the Philippines and North Borneo as well as their geographical propinquity, the Ministers agreed that in joining the proposed Federation of Malaysia the Government of the latter and the Government of the Philippines should maintain the harmony and the friendly relations subsisting the security and stability of the area.

Meeting of Heads of Government

14. The Ministers agreed to recommend that a meeting of their respective Heads of Government be held in Manila not later than the end of July 1963

15. The Ministers expressed satisfaction over the atmosphere of brotherhood and cordiality which pervaded their Meeting and considered it as a confirmation of their close fraternal ties and as a happy augury for the success of future consultations among their leaders.

16. the Ministers agreed to place on record their profound appreciation of the statesmanlike efforts of President Macapagal whose courage, vision and inspiration not only facilitated the holding of this historic Meeting but also contributed towards the achievement for the first time of 
a unity of purpose and a sense of common dedication among the peoples of Malaya, Indonesia and the Philippines.

\section{APPROVED AND ACCPETED}

Manila, July 31, 1963

\section{SOEKARNO}

President of the

Republic of Indonesia

\section{DIOSDADO MACAPGAL}

President of the Philippines

\section{TUNKU ABDUL RAHMAN PUTRA AL HAJ}

Prime Minister of the Federation of Malaya 